\title{
木鋼ハイブリッドラチスシェル接合部の面外負方向および面内方向回転剛性 ROTATIONAL STIFFNESS OF STEEL CONNECTIONS FOR TIMBER LATTICE SHELL IN NEGATIVE OUT-OF-PLANE AND IN-PLANE DIRECTIONS
}

中島 舜*1, 山崎義弘 *2, 坂田弘安*3,

竹内徹*3, 原田公明*4, 林 賢一 ${ }^{* 5}$

\section{Shun NAKAJIMA, Yoshihiro YAMAZAKI, Hiroyasu SAKATA, Toru TAKEUCHI, Hiroaki HARADA and Kenichi HAYASHI}

\begin{abstract}
The authors have proposed effective steel connections achieving high bending stiffness and strength for timber grid-shell structures in the previous research. However, their performance against negative out-of-plane and in-plane directions which affect the shell buckling strength are not clear yet. In this research, the bending performance of the proposed connections against negative out-of-plane and in-plane directions are confirmed through real-size mock-up tests. They are compared to the performance against positive out-of-plane. Formulas for evaluating the stiffness and strength of the connections against these directions are proposed, and their validity are verified by comparing with the test results.
\end{abstract}

Keywords : Composite Structure, Timber Structure, Lattice Shell, Connection, Rotational Stiffness, Bending Strength 複合構造，木質構造，ラチスシェル，接合部，回転岡性，曲け耐力

\section{1. 序}

近年，建築分野において木材利用が促進され，単層ラチスシェル 屋根構造に木質材を用いる事例も増加している。木質ラチスシェル 構造においては接合部の回転剛性がその座屈荷重に及ぼす影響が大 きいと考えられるが，その研究事例はまだ少ない。これらの接合部 においては面外方向および面内方向の曲げに対する剛性および耐力 がそれぞれ異なる場合が多く，各方向における接合部特性の把握お よびそれぞれの座屈荷重への影響を確認する必要がある。

筆者ら ${ }^{1)}$ は Fig. 1 に示寸ようなスパン $24 \mathrm{~m} \times 24 \mathrm{~m}$, ライズ $3.2 \mathrm{~m}$ の 鋼製接合部を有する木鋼ハイブリッド単層直交格子ラチスシェル （以降，木鋼シェル）を想定した接合部を 5 種類提案し，実大曲げ 実験より自重で受ける面外正方向の曲げに対する接合部の回転剛性 および曲げ耐力を明らかにした。本接合部は鋼材の中央に配置した 鋼管と集成材の木口面を接触させ， $\mathrm{T}$ 形または $\mathrm{H}$ 形断面のブラケッ トのフランジとラグスクリューを通じて集成材に曲げモーメントを 伝達することを特徵とする。従来の木質接合部と比較し, 高い曲げ 剛性および曲げ耐力を有することが確認されている。

本研究では, 文献 1)で提案した 5 種類の接合部の中で構造的合理

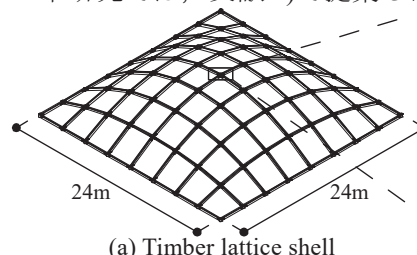

(a) Timber lattice shell

Fig. 1 Timber lattice shell roo
性および接合効率の優れた Fig. 2 に示す TB300, TB440 および HB の 3 種類について，まず未だ明らかでない面外負方向および面内方 向の曲げに対する接合部の回転剛性および曲げ耐力を実大曲げ実験 により明らかにし，さらに数值解析を用いた接合部挙動の再現およ び完全弾塑性型の曲げモーメント $M$-回転角 $\theta$ 関係の評価手法を提 案し，その有効性を確認する。

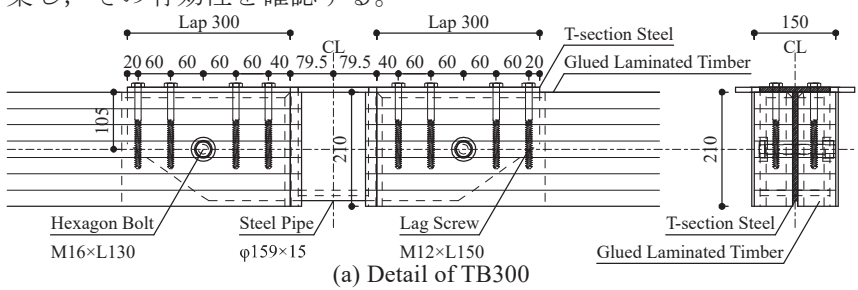

(a) Detail of TB300

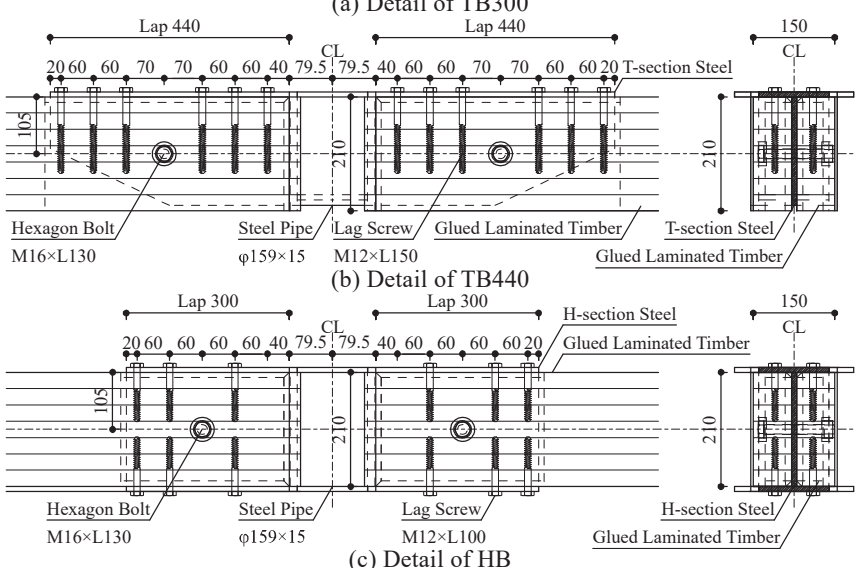

Fig. 2 Composition of proposed connection
*1 元 東京工業大学建築学系 大学院生 $\cdot$ 修士 (工学) (現 株日本設計)

*2 東京工業大学建築学系 助教・博士 (工学)

*3 東京工業大学建築学系 教授・博士 (工学)

*4 (秼)日建設計 修士(工学)

*5 日鉄エンジニアリング株) 修士(工学)
Former Grad. Student, Dept. of Arch. and Build. Eng., Tokyo Institute of Technology, M.Eng. (NIHON SEKKEI, INC.)

Assist. Prof., Dept. of Arch. and Build. Eng., Tokyo Institute of Technology, Dr.Eng. Prof., Dept. of Arch. and Build. Eng., Tokyo Institute of Technology, Dr.Eng. NIKKEN SEKKEI, M.Eng.

Nippon Steel Engineering Co., Ltd., M.Eng. 


\section{2. 解析による接合部の $M-\theta$ 関係の評価手法の提案}

\section{1. 接合部の解析モデルの構築}

TB300 および TB440 の面外負方向，TB300，TB440 および HB の 面内方向曲げに対する接合部の詳細解析を試みる。 $\theta$ の増分 $\Delta \theta$ を 設定し， $\Delta \theta$ ごとに $\theta$ を増分させ，逐次繊維直交方向および䋊維方 向の中立軸 $X_{n i}$ および $Y_{n i}$ を $\Delta \theta$ ごとに収斂計算により求めること で $M-\theta$ 関係を導く。Fig. 3 亿示すように, 接合部に $M$ が作用した 時の抵抗メカニズムを想定し, 接合部内で繊維直交方向および纎維 方向に発生する各抵抗力の釣り合いより各諸量を求める ${ }^{1)}$ 作用した時に生じる $\theta$ に伴う各抵抗力を $P$ とし接合部内に発生す る $P$ を以下に定義する。 $\theta$ は実験の計測点と対応するように集成 材の部材芯と鋼材の相対回転角の増分と寸る。面外負方向で考慮し たラグスクリューによるプレストレスはカ学モデルの妥当性を検証 するため実験と比較する詳細解析では考慮するが，長期的に維持で きないものと考えられるため, 構造検討上はモデルの簡易化も加味 して考慮しない。施工時の容易性を求め, 集成材のスリットとウェ ブに $2 \mathrm{~mm}$ の隙間があり, 面内方向ではウェブによる集成材へのめ り込みによる抵抗力は無視できるほど小さいとする。

\section{2. 面外負方向での TB300, TB440 の $M-\theta$ 関係の算出}

Fig. 3 (a-1)，(a-2)に示す面外負方向では上端のラグスクリューの プレストレスによる抵抗力のうち，フランジと集成材の接触部分に おける抵抗力 $P_{l p . y . t i}$ は式(1), 余長の寄与分における抵抗力 $P_{l p . y . t o}$ は 式(2), 上端のラグスクリューの引抜による抵抗力 $P_{l t . t i}$ は式(3), 上 端のラグスクリューのせん断による抵抗力 $P_{l s . t}$ は式(4), 上端のフ ランジによる集成材へのめり込みによる抵抗力 $P_{t e . y . t i}$ は式(5), 上 端のラグスクリューのプレストレスにおける集成材と鋼材間に働く 摩擦力のうち, フランジと集成材の接触部分における摩擦力 $P_{l p f . x . t i}$ は式(6), 余長の寄与分における摩擦力 $P_{l p f . x . t o}$ は式(7), 上端のフラ ンジと集成材間に働くフランジと集成材の接触部分における摩擦力 $P_{\text {tef.x.ti }}$ は式(8), 繊維直交方向に生じる六角ボルトのめり込みによ る抵抗力 $P_{h e . y}$ は式(9), 繊維方向に生じる六角ボルトのめり込みに よる抵抗力 $P_{h e . x}$ は式(10), 回転中心を中心とする円の接線方向に生 じる六角ボルトのめり込みによる抵抗力 $P_{h e}$ は式(11), 繊維方向に 生じる鋼管の集成材へのめり込みによる抵抗力 $\left.P_{t e . x}{ }^{3}\right)$ は式(12), 繊 維直交方向に生じる集成材と鋼管面に働く摩擦力 $P_{\text {tef. } y}$ は式(13) と する。接合部が回転することにより集成材と鋼管の間隙が無くなり， 集成材と鋼管が接触し， $P_{\text {te. } x}$ が生じる判定として $Y_{\text {g.o }}$ を用いる。

$$
\begin{aligned}
& P_{l p . y . t i}=(1 / 2) E_{90}\left\{\theta\left(L-X_{n i}\right) / h_{l p}\right\} b\left(L-X_{n i}\right) \\
& P_{l p . y . t o}=(1 / 2) E_{90}\left\{\theta\left(L-X_{n i}\right) / h_{l p}\right\} b(h / 2) \\
& P_{l t . t i}=\sum_{i} K_{l t} n_{l t . t i} \theta\left(L-X_{n i}-X_{l t . t i}\right) \\
& P_{l s . t}=K_{l s . h} n_{l s . t} \theta Y_{n i} \\
& \text { (4), } P_{\text {te.y.ti }}=(1 / 2) E_{90}\left(\theta X_{n i} / h\right) b X_{n i} \\
& P_{l p f \cdot x . t i}=P_{l p . y . t i} \mu \\
& \text { (6), } P_{l p f . x . t o}=P_{l p . y . t o} \mu \\
& P_{\text {tef.x.ti }}=P_{\text {te.y.ti }} \mu \\
& \text { (8), } P_{\text {he. } y}=P_{h e} \cos \varphi_{\text {he }} \\
& P_{\text {he. }}=P_{h e} \sin \varphi_{\text {he }} \\
& \text { (10), } P_{h e}=K_{h e}\left\{\left(X_{n i}-\alpha L\right) / \cos \varphi_{h e}\right\} \theta \\
& P_{\text {te. } x}=(1 / 2) Y_{\text {g.o }}{ }^{2} b_{1} k_{0 c} \theta \\
& \text { (12), } P_{\text {tef. } y}=P_{\text {te. } x} \mu
\end{aligned}
$$

ただし $L$ は鋼材と集成材のラップ長, $X_{n i}$ は集成材端部（Fig. 3 中

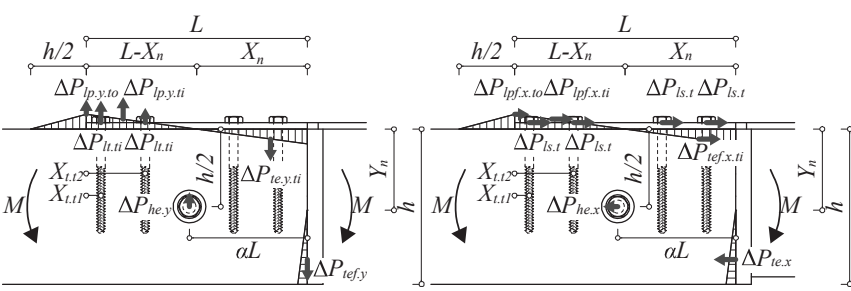

(a-1) Perpendicular to grain (Negative out-of-plane)

(a-2) Parallel to grain (b-1) Perpendicular to grain (In-plane)

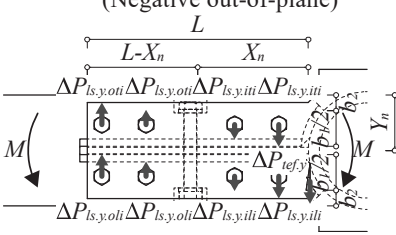
(Negative out-of-plane)

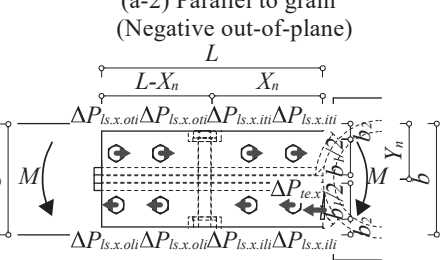

(b-2) Parallel to grain (In-plane)
の右端）から中立軸までの距離， $X_{l t . t i}$ は集成材上端の鋼管側端部 (Fig. 3 中の右端) から引抜として働く各ラグスクリューまでの距 離, $Y_{n i}$ は集成材上端から中立軸までの距離, $h$ は集成材の梁せい, $b$ は有効集成材幅, $b_{1}$ は集成材と鋼管の接触面の見付け幅, $h_{l p}$ は プレストレスを考慮したラグスクリューの有効深さ， $E_{0}$ および $E_{90}\left(=E_{0} / 25\right)^{4}$ は集成材の繊維方向および繊維直交方向の圧縮に対 するヤング率, $K_{l t}$ はラグスクリューの引抜剛性 ${ }^{5}$ ) (付録 $\left.\mathrm{A}\right), K_{l s . v}$ および $K_{l s . h}$ は纎維直交方向および䋊維方向に対するラグスクリュ 一のせん断岡性 ${ }^{6}$ （付録 $\left.\mathrm{A}\right), K_{h e}$ は荷重角度を考慮してハンキンソ ン式を用いた回転中心を中心とする円の接線方向に対する六角ボル トのめり込み剛性， $K_{j s . v}$ および $K_{j s . h}$ は繊維直交方向および繊維方 向に対する六角ボルトのめり込み剛性 6)（付録 A）， $n_{l t . t i}$ は位置 $X_{t . t i}$ における引抜が生じるラグスクリューの本数, $n_{l s . t}$ は上端のラ グスクリューの本数， $\alpha$ はラップ長に対する集成材端部から六角 ボルトまでの距離の比率， $\mu$ は動摩擦係数， $k_{0 c}$ は繊維方向に対す る集成材の面圧剛性 ${ }^{3)}$ (付録 $\mathrm{A}$ ）， $\varphi_{h e}$ は回転中心を基点に六角ボル 卜位置での繊維方向に対する荷重角度， $Y_{g . o}$ は集成材の木口と鋼管 との接触面の距離， $X_{\text {gap }}$ は初期状態での集成材と鋼管の間隙の距 離である。

ここで，上端の集成材幅 $150 \mathrm{~mm}$ は鋼材幅 $130 \mathrm{~mm}$ に対して大きい が，集成材の余端に十分なめり込みによる抵抗力が見込めるとし， $b$ は集成材幅からスリット幅 $11 \mathrm{~mm}$ を除いた長さである $139 \mathrm{~mm}$ と する。 $h_{l p}$ はラグスクリューの長さに等しく, TB300, TB440 およ び PB は $150 \mathrm{~mm} ， \mathrm{BB}$ は $125 \mathrm{~mm}$ とする。 $\alpha$ は TB $300 ， \mathrm{~PB}$ およ゙ $\mathrm{HB}$ は 16/30, TB440 は23/44, $b_{1}$ は $72 \mathrm{~mm}$ とする。文献 7)を参照し $\mu$ は 0.2 とする。ラップ外におけるめり込み抵抗が影響する距離は文 献 1)，8)を参照し，集成材のせい $h$ に対して $h / 2$ とする。 $Y_{g . o}$ が 負の值の場合は 0 とする。 $X_{\text {gap }}$ は $0.2 \mathrm{~mm}$ とする。

回転角 $\theta$ に対する繊維直交方向および繊維方向に対する各抵抗力 のつり合いである式(17)，(18)より $X_{n i}$ および $Y_{n i}$ を算出する。これ らは $X_{n i}$ および $Y_{n i}$ に関する 2 元 3 次連立方程式となるため, 収斂 計算を用いる必要がある。

$P_{y}=P_{l p . y . t i}+P_{l p . y . t o}+P_{l t . t i}+P_{h e . y}-\left(P_{t e . y . t i}+P_{t e f . y}\right)=0$

$P_{x}=P_{l p f . x . t i}+P_{l p f . x . t o}+P_{\text {tef. } x . t i}+P_{l s . t}-\left(P_{\text {he. } x}+P_{\text {te. } x}\right)=0$

弾性時において $P_{*}$ に起因寸る抵抗モーメントを $M_{*}$ と表記する。

$M_{l p . y . t i}=(1 / 2) E_{90}\left\{\theta\left(L-X_{n i}\right) / h_{l p}\right\} b\left(L-X_{n i}\right)(2 / 3)\left(L-X_{n i}\right)$ 


$$
\begin{aligned}
& M_{l p . y . t o}=(1 / 2) E_{90}\left\{\theta\left(L-X_{n i}\right) / h_{l p}\right\} b(h / 2)(2 / 3)\left(L-X_{n i}\right) \\
& M_{l t . t i}=\sum_{i} K_{l t} n_{l t . t i} \theta\left(L-X_{n i}-X_{l t . t i}\right)^{2} \quad(21), \quad M_{l s . t}=K_{l s . h} n_{l s . t} \theta Y_{n i}{ }^{2} \\
& M_{\text {te. } y . t i}=(1 / 2) E_{90}\left(\theta X_{n i} / h\right) b X_{n i}(2 / 3) X_{n i} \\
& M_{l p f . x . t i}=P_{l p . y . t i} \mu Y_{n i} \quad \text { (24), } M_{l p f . x . t o}=P_{l p . y . t o} \mu Y_{n i} \\
& M_{\text {tef.x.ti }}=P_{\text {te. } y . t i} \mu Y_{n i} \quad \text { (26), } M_{h e}=K_{h e}\left\{\left(X_{n i}-\alpha L\right) / \cos \varphi_{h e}\right\}^{2} \theta \\
& M_{\text {te. } x}=(1 / 2) Y_{\text {g.o }}{ }^{2} b_{1} k_{0 c} \theta(2 / 3)\left(h-Y_{n i}\right) \quad \text { (28), } M_{\text {tef. } y}=P_{\text {te. } x} \mu X_{n i} \\
& M \text { は各抵抗モーメントの和として式(30)とする。 } \\
& M=M_{l p . y . t i}+M_{l p . y . t o}+M_{l t . t i}+M_{l s . t}+M_{t e . y . t i} \\
& +M_{l p f . x . t i}+M_{l p f . x . t o}+M_{t e f . x . t i}+M_{h e}+M_{t e . x}+M_{t e f . y}
\end{aligned}
$$

塑性化後において, ラグスクリューの引抜による抵抗力, ラグス クリューのせん断による抵抗力および六角ボルトのめり込みによる 抵抗力は一定とする。弾性時における $P_{*}$ に起因する塑性化後の抵 抗力を $P_{* 2}$ と表記する。塑性化後のめり込みによる抵抗力を考慮す る際, $P_{\text {te.y.ti.2 }}$ ではひずみ度分布形状は塑性域でも変化せず, 集成 材のめり込み降伏ひずみを超えるひずみ度に対しては, 集成材の繊 維直交方向の圧縮に対する応力度-ひずみ度関係の第二勾配のヤン グ率を用いることで塑性化後の応力上昇を考慮し ${ }^{2)}, P_{t e . x .2}$ では応 力度分布形状は塑性域で変化し, 集成材の基準支圧強度 $F_{e}$ を超え る応力度に対しては, 集成材の繊維方向の圧縮に対する応力度-ひ ずみ度関係の第二勾配のヤング率を用いることで塑性化後の応力上 昇を考慮する。塑性化後の繊維直交方向および繊維方向に対する各 抵抗力のつり合いは, 式(17), (18)の弾性時の各抵抗力を塑性時の 各抵抗力に置き換えた釣り合いの式とする。ラグスクリューによる プレストレスの効果が無くなる時の回転角である第 1 折れ点回転角 $\theta_{1}$ は式(48)より求める。

$$
\begin{aligned}
& P_{l t . t i .2}=\sum_{i} K_{l t} n_{l t . t i} \theta_{u . l t . t i}\left(L-X_{n i}-X_{l t . t i}\right) \\
& P_{l s . t .2}=K_{l s . h} n_{l s . t} \theta_{\text {u.ls.t }} Y_{n i} \\
& P_{\text {te.y.ti.2 }}=(1 / 2) E_{90}\left(\theta X_{n i} / h\right) b X_{n i}\left\{1-\left(1-E_{90.2} / E_{90}\right)\left(1-\varepsilon_{y .90} / \varepsilon_{90}\right)^{2}\right\} \\
& P_{\text {tef.x.ti.2 }}=P_{\text {te.y.ti. } 2} \mu \quad \text { (34), } P_{\text {he. } .2}=P_{h e .2} \cos \varphi_{h e} \\
& P_{\text {he.x.2 }}=P_{h e .2} \sin \varphi_{h e} \quad \text { (36), } P_{h e .2}=K_{h e}\left\{\left(X_{n i}-\alpha L\right) / \cos \varphi_{h e}\right\} \theta_{u . h e} \\
& P_{\text {te.x.2 }}=(1 / 2) Y_{\text {g.o }}{ }^{2} b_{1} k_{0 c} \theta\left\{1-\left(1-E_{0.2} / E_{0}\right)\left(1-\theta_{\text {u.tex.out }} / \theta\right)^{2}\right\} \\
& P_{\text {tef.y.2 }}=P_{\text {te. } x .2} \mu \\
& \theta_{u . h e}=\arctan \left[\left\{\delta_{u . h e} /\left(X_{n i}-\alpha L\right)\right\} \cos \varphi_{h e}\right] \quad(40), \quad \delta_{u . h e}=P_{u . h e} / K_{h e} \\
& P_{u . h e}=P_{u \text { u.heh }} P_{\text {u.he. }} /\left\{P_{\text {u.he.h }} \sin ^{2}\left(\pi / 2-\varphi_{\text {he }}\right)+P_{\text {u.he.v }} \cos ^{2}\left(\pi / 2-\varphi_{h e}\right)\right\} \\
& \theta_{u . l t . t i}=\left\{\delta_{u . l t}(1-r)\right\} /\left(L-X_{n i}-X_{t . t i}\right) \quad \text { (43), } \theta_{u . l s . t}=\delta_{u . l s} / Y_{n i} \\
& \theta_{\text {u.tex.x.out }}=F_{e} /\left(Y_{g . o} k_{0 c}\right) \quad(45), E_{0.2}=0 \quad(46), E_{90.2}=E_{90} / 55 \\
& \theta_{1}=\left(P_{0 l} n_{l s . t} / A_{l a p} E_{90}\right)\left(h_{l p} / L-X_{n i}\right) \quad \text { (48), } P_{0 l}=r P_{y l}
\end{aligned}
$$

ただし $\varepsilon_{90}$ は $P_{t e . y . t i}$ による集成材のめり込み縁ひずみ, $\varepsilon_{y .0}$ および $\varepsilon_{y .90}$ は繊維方向および纎維直交方向における集成材のめり込み降 伏ひずみ， $E_{0.2}$ および $E_{90.2}$ は繊維方向および䋊維直交方向におけ る集成材の圧縮に対する応力度-ひずみ度関係の第二勾配のヤング 率, $P_{u, h e . h}$ および $P_{u . h e . v}$ は繊維方向および䋊維直交方向に対する六 角ボルトのめり込みによる終局耐力 ${ }^{\circ}$ (付録 A)， $P_{0 l}$ は初期のプレ ストレスに寄与しているラグスクリューの引抜力， $P_{y l}$ はラグスク リューの引抜による降伏耐力 $)\left(\right.$ 付録 A), $A_{\text {lap }}$ は集成材と鋼材の ラップ面積, $r$ は $P_{y l}$ に対する $P_{0 l}$ の寄与率である。

ここで, 文献 8)を参照し $\varepsilon_{y .90}$ は 0.0063 , 文献 6)を参照し $F_{e}$ は $25.4 \mathrm{~N} / \mathrm{mm}^{2}$ とする。 $P_{0 l}$ は $P_{y l}$ の $10 \%$ と仮定し $r$ は 0.1 とする。
塑性化後において， $P_{* .2}$ に起因する抵抗モーメントを $M_{* .2}$ と表 記する。塑性化後の $M$ は式(30)の弾性時の各抵抗モーメントを塑 性時の各抵抗モーメントに置換した式とする。

$$
\begin{aligned}
& M_{l t . t i .2}=\sum_{i} K_{l t} n_{\text {lt.ti }} \theta_{\text {u.lt.ti }}\left(L-X_{n i}-X_{\text {lt.ti }}\right)^{2} \\
& M_{l s . t .2}=K_{l s . h} n_{l s . t} \theta_{\text {u.ls.t. }} Y_{n i}^{2} \\
& M_{\text {te.y.ti.2 }}=(1 / 2) E_{90}\left(\theta X_{n i} / h\right) b X_{n i}(2 / 3) X_{n i} \\
& \times\left\{1-\left(1-E_{90.2} / E_{90}\right)\left(1+(1 / 2) \varepsilon_{y .90} / \varepsilon_{90}\right)\left(1-\varepsilon_{y .90} / \varepsilon_{90}\right)^{2}\right\} \\
& M_{\text {tef.x.ti.2 }}=P_{\text {te.y.ti. } 2} \mu Y_{n i} \\
& M_{h e .2}=K_{h e}\left\{\left(X_{n i}-\alpha L\right) / \cos \varphi_{h e}\right\}^{2} \theta_{u . h e} \\
& M_{\text {te.x. } 2}=(1 / 2) Y_{\text {g.o }}{ }^{2} b_{1} k_{0 c} \theta(2 / 3)\left(h-Y_{n i}\right) \\
& \times\left\{1-\left(1-E_{0.2} / E_{0}\right)\left(1+(1 / 2) \theta_{\text {u.te.x.out }} / \theta\right)\left(1-\theta_{\text {u.te.x.out }} / \theta\right)^{2}\right\}
\end{aligned}
$$

$M_{\text {tef. } y .2}=P_{\text {te. } x .2} \mu Y_{n i}$

ラグスクリューの引抜での集成材の割裂破壊による終局耐力 $P_{u w . l t}$ は式(57)とする。

$P_{u w . l t}=\{2 / \sin (\pi / 2)\} C_{r}(b / 2) \sqrt{l_{2} /\left(1-l_{2} / h\right)}$

ただしラグスクリューの先端で割裂が生じると仮定し， $l_{2}$ はラグ スクリューの埋め込み有効長さである。 $C_{r}$ は割裂破壊定数（付録 A）である。

ラグスクリューの引抜により集成材に割裂が生じる時の回転角 $\theta_{u w . l t}$ は $P_{l t . t i}$ が $P_{u w . l t}$ に達した時の $\theta$ とし, 式(58)とする。

$\theta_{u w . l t}=\arctan \left\{\left(n_{l t . t i} P_{u w . l t} / K_{l t}\right) /\left(L-X_{n i}-X_{l t . t i}\right)\right\}$

$\theta$ が $\theta_{u w . l t}$ に到達した後では, 集成材の割裂は拡大し, 集成材の 平面保持の仮定は成立せず, 割裂発生後の実現象の挙動を追跡する ことは難しいため, $\theta$ が $\theta_{u w . l t}$ に到達する前での挙動が適用範囲と なる。

\section{3. 面内方向での $\mathrm{TB} 300, \mathrm{~TB} 440, \mathrm{HB}$ の $M-\theta$ 関係の算出}

Fig. 3 (b-1)，(b-2)に示寸面内方向では六角ボルトを境に内側（鋼 管側）の上列のラグスクリューにおける回転中心を中心とする円の 接線方向のせん断による抵抗力 $P_{l s . i t i}$ は式(59), 外側（鋼材のフラン ジ端側）の上列のラグスクリューにおける接線方向のせん断による 抵抗力 $P_{l s . o t i}$ は式(60), 内側の下列のラグスクリューにおける接線 方向のせん断による抵抗力 $P_{l s . i l}$ は式(61), 外側の下列のラグスクリ ユーにおける接線方向のせん断による抵抗力 $P_{l s . o l i}$ は式(62), 繊維 方向に生じる鋼管の集成材へのめり込みによる抵抗力 $P_{t e . x}{ }^{3)}$ は式 (63), 繊維直交方向に生じる集成材と鋼管面に働く摩擦力 $P_{t e f . y}$ は 式(64)とする。接合部が回転することにより集成材と鋼管の間隙の 距離が無くなり, 集成材と鋼管が接触し， $P_{t e . x}$ が生じる判定とし て $Y_{g . i}$ を用いる。

$$
\begin{aligned}
& P_{l s . i t i}=\sum_{i} K_{l s . i t i} n_{l s . i t i} \frac{X_{n i}-X_{l s . i i}}{\cos \varphi_{l s . i t i}} \theta \\
& P_{\text {ls.oti }}=\sum_{i} K_{\text {ls.oti }} n_{l s . o t i} \frac{L-X_{n i}-X_{\text {ls.oi }}}{\cos \varphi_{\text {ls.oti }}} \theta \\
& P_{l s . i l i}=\sum_{i} K_{l s . i l i} n_{l s . i l i} \frac{X_{n i}-X_{l s . i i}}{\cos \varphi_{l s . i l i}} \theta \\
& P_{\text {ls.oli }}=\sum_{i} K_{\text {ls.oli }} n_{l s . o l i} \frac{L-X_{n i}-X_{\text {ls.oi }}}{\cos \varphi_{\text {ls.oli }}} \theta \\
& P_{\text {te. } x}=(1 / 2) Y_{g . i}{ }^{2} h k_{0 c} \theta \quad \text { (63), } P_{\text {tef. } y}=P_{\text {te. } x} \mu \\
& P_{l s . y . t i}=P_{l s . t i} \cos \varphi_{l s . i t i} \quad \text { (65), } P_{l s . y . o t i}=P_{l s . o t i} \cos \varphi_{l s . o t i} \\
& P_{l s . \text {. . ili }}=P_{l s . i l i} \cos \varphi_{l s . i l i} \quad \text { (67), } P_{l s . \text {. .oli }}=P_{l s . o l i} \cos \varphi_{l s . o l i}
\end{aligned}
$$


$P_{l s . x . i t i}=P_{l s . i t i} \sin \varphi_{l s . i t i}$

(69), $\quad P_{l s . x . o t i}=P_{l s . o t i} \sin \varphi_{l s . o t i}$

(70)

$P_{l s . x . i l i}=P_{l s . i l i} \sin \varphi_{l s . i l i}$

(71), $P_{l s . x . o l i}=P_{l s . o l i} \sin \varphi_{l s . o l i}$

$K_{l s . i t i}=K_{l s . h} K_{l s . v} /\left\{K_{l s . h} \sin ^{2}\left(\pi / 2-\varphi_{l s . i t i}\right)+K_{l s . v} \cos ^{2}\left(\pi / 2-\varphi_{l s . i t i}\right)\right\}$

$K_{l s . o t i}=K_{l s . h} K_{l s . v} /\left\{K_{l s . h} \sin ^{2}\left(\pi / 2-\varphi_{l s . o t i}\right)+K_{l s . v} \cos ^{2}\left(\pi / 2-\varphi_{l s . o t i}\right)\right\}$

$K_{l s . i l i}=K_{l s . h} K_{l s . v} /\left\{K_{l s . h} \sin ^{2}\left(\pi / 2-\varphi_{l s . i l i}\right)+K_{l s . v} \cos ^{2}\left(\pi / 2-\varphi_{l s . i l i}\right)\right\}$

$K_{l s . o l i}=K_{l s . h} K_{l s . v} /\left\{K_{l s . h} \sin ^{2}\left(\pi / 2-\varphi_{l s . o l i}\right)+K_{l s . v} \cos ^{2}\left(\pi / 2-\varphi_{l s . o l i}\right)\right\}$

$\varphi_{l s . i t i}=\arctan \frac{Y_{n i}-Y_{l s . t i}}{X_{n i}-X_{l s . i i}}$

(77), $\varphi_{l s . o t i}=\arctan \frac{Y_{n i}-Y_{l s . t i}}{L-X_{n i}-X_{l s . o i}}$

$\varphi_{l s . i l i}=\arctan \frac{b_{0}-Y_{n i}-Y_{l s . l i}}{X_{n i}-X_{l s . i i}}$

(79), $\varphi_{l s . o l i}=\arctan \frac{b_{0}-Y_{n i}-Y_{l s . l i}}{L-X_{n i}-X_{l s . o i}}$

$Y_{g . i}=b_{0}-Y_{n i}-b_{2}-X_{\text {gap }} / \theta$

ただし $X_{l s . i i}$ は鋼管側端部（Fig. 3 中の右端）から繊維直交方向のせ ん断として働く各ラグスクリューまでの距離, $X_{l s . o i}$ はフランジ端 部（Fig. 3 中の左端）から纎維直交方向のせん断として働く各ラグ スクリューまでの距離, $Y_{l s . t i}$ は集成材上端（Fig. 3 中は上端）から 纎維方向のせん断として働く各ラグスクリューまでの距離, $Y_{l s . l i}$ は集成材下端（Fig. 3 中の下端）から繊維方向のせん断として働く 各ラグスクリューまでの距離, $b_{0}$ は集成材幅, $b_{2}$ は集成材端部か ら鋼管との接触面の距離, $n_{l s . i t i}$ は位置 $X_{l s . i i}$ および $Y_{l s . t i}, \quad n_{l s . o t i}$ は位置 $X_{l s . o i}$ および $Y_{l s . t i}, \quad n_{l s . i l i}$ は位置 $X_{l s . i i}$ および $Y_{l s . l i}, \quad n_{l s . o l i}$ は位置 $X_{l s . o i}$ および $Y_{l s . l i}$ におけるせん断が生じるラグスクリュー の本数, $Y_{g . i}$ は集成材の木口と鋼管との接触面の距離である。

ここで， $Y_{l s . t i}$ および $Y_{l s . l i}$ は $40 \mathrm{~mm} ， b_{0}$ は $150 \mathrm{~mm} ， b_{2}$ は $21 \mathrm{~mm}$ と し， $Y_{g . i}$ が負の值の場合は 0 とする。

$\theta$ に対する繊維直交方向および䋊維方向に対する各抵抗力のつ り合いである式(82), (83)より $X_{n i}$ および $Y_{n i}$ を算出する。これらは $X_{n i}$ および $Y_{n i}$ に関する 2 元 3 次連立方程式となるため, 収斂計算 を用いる必要がある。

$P_{y}=P_{l s . y . o t i}+P_{l s . y . o l i}-\left(P_{l s . y . i t i}+P_{l s . y . i l i}+P_{\text {tef.y }}\right)=0$

$P_{x}=P_{l s . x . i t i}+P_{l s . x . o t i}-\left(P_{l s . x . i l i}+P_{l s . x . o l i}+P_{\text {te. } x}\right)=0$

弾性時において $P_{*}$ に起因する抵抗モ一メントを $M_{*}$ と表記する。

$M_{l s . i t i}=\sum_{i} K_{l s . i t i} n_{l s . i t i}\left\{\left(X_{n i}-X_{l s . i i}\right) / \cos \varphi_{l s . i t i}\right\}^{2} \theta$

$M_{\text {ls.oti }}=\sum_{i} K_{\text {ls.oti }} n_{\text {ls.oti }}\left\{\left(L-X_{n i}-X_{\text {ls.oi }}\right) / \cos \varphi_{\text {ls.oti }}\right\}^{2} \theta$

$M_{l s . i l i}=\sum_{i} K_{l s . i l i} n_{l s . i l i}\left\{\left(X_{n i}-X_{l s . i i}\right) / \cos \varphi_{l s . i l i}\right\}^{2} \theta$

$M_{\text {ls.oli }}=\sum_{i} K_{l s . o l i} n_{l s . o l i}\left\{\left(L-X_{n i}-X_{\text {ls.oi }}\right) / \cos \varphi_{\text {ls.oli }}\right\}^{2} \theta$

$M_{t e . x}=(1 / 2) Y_{g . i}{ }^{2} h k_{0 c} \theta(2 / 3)\left(b_{0}-Y_{n i}-b_{2}\right)$

$M_{\text {tef. } y}=P_{\text {te. } x} \mu X_{n i}$

$M$ は各抵抗モーメントの和として式(90)とする。 $\theta$ は接合部内 における集成材のせん断および曲げ変形を加味して低減した $\theta_{r}$ と して式(91)とする。 $M-\theta$ 関係に用いる $\theta$ は $\theta_{r}$ とする。 $K_{\theta}$ は曲げ による寄与を Fig. 4 に示すように考慮する。

$M=M_{l s . i t i}+M_{l s . o t i}+M_{l s . l i}+M_{l s . o l i}+M_{t e . x}+M_{t e f . y}$
$\theta_{r}=M\left[\frac{1}{M / \theta}+\frac{1}{E_{0} b^{3} h /(4 L)}+\frac{1}{\left(E_{0} / 15\right) b h L}\right]$

塑性化後において, ラグスクリューのせん断による抵抗力は一定 とする。弾性時における $P_{*}$ に起因する塑性化後の抵抗力を $P_{* .2}$ と 表記する。塑性化後のめり込みによる抵抗力を考慮する際, $P_{\text {tex. } 2}$ では応力度分布形状は塑性域で変化し, 集成材の基準支圧強度 $F_{e}$

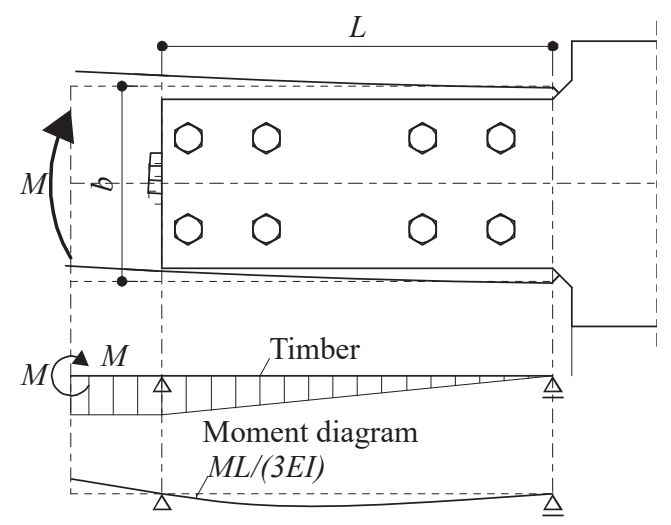

Deformation diagram

Fig. 4 Contribution to deformation by bending

を超える応力度に対しては, 集成材の繊維方向の圧縮に対する応力 度-ひずみ度関係の第二勾配のヤング率を用いることで塑性化後の 応力上昇を考慮する。塑性化後の䋊維直交方向および繊維方向に対 する各抵抗力のつり合いは，式(82)，(83)の弾性時の各抵抗力を塑 性時の各抵抗力に置き換えた釣り合いの式とする。

$$
\begin{aligned}
& P_{l s . y . i t i .2}=P_{l s . i t i .2} \cos \varphi_{l s . i t i} \\
& \text { (92), } \quad P_{l s . y . o t i .2}=P_{l s . o t i .2} \cos \varphi_{l s . o t i} \\
& P_{\text {ls.y.ili.2 }}=P_{l s . i l i .2} \cos \varphi_{l s . i l i} \\
& \text { (94), } P_{l s . y . o l i .2}=P_{l s . o l i .2} \cos \varphi_{l s . o l i} \\
& P_{l s . x \text {. it } .2}=P_{l s . i t .2} \sin \varphi_{l s . i t i} \\
& \text { (96), } \quad P_{\text {ls.x.oti. } 2}=P_{\text {ls.oti.2 }} \sin \varphi_{\text {ls.oti }} \\
& P_{l s . x . i l i .2}=P_{l s . i l i .2} \sin \varphi_{l s . i l i} \\
& \text { (98), } \quad P_{l s . x . o l i .2}=P_{l s . o l i .2} \sin \varphi_{l s . o l i} \\
& P_{\text {te.x. } 2}=(1 / 2) Y_{g . i}{ }^{2} h k_{0 c} \theta\left\{1-\left(1-E_{0.2} / E_{0}\right)\left(1-\theta_{\text {u.te.x }} / \theta\right)^{2}\right\} \\
& P_{\text {tef. } y .2}=P_{\text {te. } x .2} \mu \\
& P_{\text {ls.iti. } 2}=\sum_{i} K_{\text {ls.iti }} n_{\text {ls.iti }} \frac{X_{n i}-X_{\text {ls.ii }}}{\cos \varphi_{\text {ls.iti }}} \theta_{\text {u.ls.iti }} \\
& P_{l s . o t i .2}=\sum_{i} K_{l s . o t i} n_{l s . o t i} \frac{L-X_{n i}-X_{l s . o i}}{\cos \varphi_{l s . o t i}} \theta_{u . l s . o t i} \\
& P_{l s . i l i .2}=\sum_{i} K_{l s . i l i} n_{l s . i l i} \frac{X_{n i}-X_{\text {ls.ii }}}{\cos \varphi_{\text {ls.ili }}} \theta_{\text {u.ls.ili }} \\
& P_{l s . o l i .2}=\sum_{i} K_{l s . o l i} n_{l s . o l i} \frac{L-X_{n i}-X_{l s . o i}}{\cos \varphi_{l s . o l i}} \theta_{u . l s . o l i} \\
& \theta_{u \text {.tex.out }}=F_{e} /\left(Y_{g . i} k_{0 c}\right) \\
& \theta_{\text {u.ls.iti }}=\arctan \left[\left\{\delta_{\text {u.ls.iti }} /\left(X_{n i}-X_{l s . i i}\right)\right\} \cos \varphi_{l s . i t i}\right] \\
& \theta_{\text {u.ls.oti }}=\arctan \left[\left\{\delta_{\text {u.ls.oti }} /\left(L-X_{n i}-X_{\text {ls.oi }}\right)\right\} \cos \varphi_{\text {ls.oti }}\right] \\
& \theta_{u . l s . i l i}=\arctan \left[\left\{\delta_{u . l s . i l i} /\left(X_{n i}-X_{l s . i i}\right)\right\} \cos \varphi_{l s . i l i}\right] \\
& \theta_{\text {u.ls.oli }}=\arctan \left[\left\{\delta_{\text {u.ls.oli }} /\left(L-X_{n i}-X_{\text {ls.oi }}\right)\right\} \cos \varphi_{\text {ls.oli }}\right] \\
& \delta_{\text {u.ls.iti }}=P_{\text {u.ls.iti }} / K_{l s . i t i} \\
& \text { (111), } \quad \delta_{\text {ulls.oti }}=P_{\text {u.ls.oti }} / K_{l s . o t i} \\
& \delta_{\text {u.ls.lil }}=P_{\text {u.ls.ili }} / K_{\text {ls. } i l i} \\
& \text { (113), } \delta_{\text {ulls.oli }}=P_{u . l s . o l i} / K_{l s . o l i} \\
& P_{u . l s . t i}=\frac{P_{u . l s . h} P_{u . l s . v}}{P_{u . l s . h} \sin ^{2}\left(\pi / 2-\varphi_{l s . i t i}\right)+P_{u . l s . v} \cos ^{2}\left(\pi / 2-\varphi_{l s . i t i}\right)} \\
& P_{\text {u.ls.oti }}=\frac{P_{\text {u.ls.h }} P_{\text {u.ls.v }}}{P_{u . l s . h} \sin ^{2}\left(\pi / 2-\varphi_{\text {ls.oti }}\right)+P_{u . l s . v} \cos ^{2}\left(\pi / 2-\varphi_{\text {ls.oti }}\right)} \\
& P_{u . l s . i l i}=\frac{P_{u . l s . h} P_{u . l s . v}}{P_{u . l s . h} \sin ^{2}\left(\pi / 2-\varphi_{l s . i l i}\right)+P_{u . l s . v} \cos ^{2}\left(\pi / 2-\varphi_{\text {ls.ili }}\right)} \\
& P_{u . l s . o l i}=\frac{P_{u . l s . h} P_{u . l s . v}}{P_{u . l s . h} \sin ^{2}\left(\pi / 2-\varphi_{l s . o l i}\right)+P_{u . l s . v} \cos ^{2}\left(\pi / 2-\varphi_{\text {ls.oli }}\right)}
\end{aligned}
$$

ただし $P_{u . l s . h}$ および $P_{u . l s . v}$ は繊維直交方向および繊維方向に対する ラグスクリューのせん断による終局耐力 ${ }^{6}$ （付録 A）である。

塑性化後において， $P_{* .2}$ に起因寸る抵抗モーメントを $M_{* .2}$ と表 記する。塑性化後の $M$ は式(90)の弾性時の各抵抗モーメントを塑 性時の各抵抗モーメントに置換した式とする。 


$$
\begin{aligned}
& M_{l s . i t .2}=\sum_{i} K_{l s . i t i} n_{l s . i t i}\left\{\left(X_{n i}-X_{l s . i i}\right) / \cos \varphi_{l s . i t i}\right\}^{2} \theta_{u . l s . t i t} \\
& M_{\text {ls.oti. } 2}=\sum K_{\text {ls.oti }} n_{l s . o t i}\left\{\left(L-X_{n i}-X_{\text {ls.oi }}\right) / \cos \varphi_{\text {ls.oti }}\right\}^{2} \theta_{\text {ulls.oti }} \\
& M_{l s . i l i .2}=\sum_{i} K_{l s . i l i} n_{l s . i l i}\left\{\left(X_{n i}-X_{l s . i i}\right) / \cos \varphi_{l s . i l i}\right\}^{2} \theta_{u . l s . i l i} \\
& M_{l s . o l i .2}=\sum_{i} K_{l s . o l i} n_{l s . o l i}\left\{\left(L-X_{n i}-X_{l s . o i}\right) / \cos \varphi_{l s . o l i}\right\}^{2} \theta_{\text {u.ls.oli }} \\
& M_{\text {te.x. }}=(1 / 2) Y_{g . i}{ }^{2} h k_{0 c} \theta(2 / 3)\left(b_{0}-Y_{n i}-b_{2}\right) \\
& \times\left\{1-\left(1-E_{0.2} / E_{0}\right)\left(1+(1 / 2) \theta_{\text {u.te.x }} / \theta\right)\left(1-\theta_{\text {u.te. }} / \theta\right)^{2}\right\}
\end{aligned}
$$

$M_{\text {tef. } y .2}=P_{t e . x .2} \mu X_{n i}$

六角ボルトを境に内側の上列のラグスクリューにおける回転中心 を中心とする円の接線方向のせん断での集成材の割裂破壞による終 局耐力 $P_{u w . l s . i t i}$ は式(125), 内側の下列のラグスクリューにおける接 線方向のせん断での集成材の割裂破壞による終局耐力 $P_{u w . l s . i l i}$ は式 (126)とする。

$$
\begin{aligned}
& P_{u w . l s . i t i}=\frac{2}{\sin \left(\pi / 2-\varphi_{\text {ls.iti }}\right)} C_{r} h \sqrt{\frac{b / 2-Y_{l s . t i}}{1-\left(b / 2-Y_{l s . t i}\right) /(b / 2)}} \\
& P_{u w . l s . l i}=\left\{2 / \sin \left(\pi / 2-\varphi_{l s . l i}\right)\right\} C_{r} h \sqrt{Y_{l s . t i} /\left\{1-Y_{l s . t i} /(b / 2)\right\}}
\end{aligned}
$$

六角ボルトを境に内側の上列のラグスクリューにおける回転中心 を中心とする円の接線方向のせん断により集成材に割裂が生じる時 の回転角 $\theta_{u w . l s . i t}$ は $P_{l s . i t i}$ が $P_{u w . l s . i t i}$ に達した時の回転角 $\theta$ とし, 式 (127) と寸る。内側の下列のラグスクリューにおける接線方向のせ ん断により集成材に割裂が生じる時の回転角 $\theta_{u w . l s . l i}$ は $P_{l s . i t i}$ が $P_{u w . l s . i t i}$ に達した時の $\theta$ とし, 式(128)とする。

$\theta_{u w . l s . i t i}=\arctan \left[\left(P_{u w . l s . i t i} / K_{l s . i t i}\right) /\left\{\left(X_{n i}-X_{l s . i i}\right) / \cos \varphi_{l s . i t i}\right\}\right]$

$\theta_{u w . l s . l i l}=\arctan \left[\left(P_{u w . l s . i l i} / K_{l s . i l i}\right) /\left\{\left(X_{n i}-X_{l s . i i}\right) / \cos \varphi_{l s . i l i}\right\}\right]$

面外負方向と同様に $\theta$ が $\theta_{u w . l s . i t i}$ および $\theta_{u w . l s . l i}$ に到達した後では, 集成材の割裂が拡大し, 集成材の平面保持の仮定は成立せず, 挙動 を追跡することは難しいため, $\theta$ が $\theta_{u w . l s . i t i}$ および $\theta_{u w . l s . i l i}$ に到達す る前での挙動の確認に留める必要がある。

\section{3. 接合部の回転剛性や曲げ耐力の評価手法の提案}

\section{1. 収斂計算を伴う評価モデルの構築}

次に 2 章の過程を簡略化した各接合部の各方向に対する回転剛性 $K_{\theta}$, 降伏曲げモーメント $M_{y}$ および終局曲げモーメント $M_{u}$ 等の 評価を試みる。Fig. 3 に示すように考慮する力学モデルは基本的に 2 章と同様であるが， $M$ が作用した時の接合部に生じる回転角の 増分 $\Delta \theta$ に伴う荷重の増分を $\Delta P$ とし, 接合部内に発生する各荷重 の増分を以下に定義する。 $\Delta \theta$ は実験の計測点と対応するように, 集成材の部材芯と鋼材の相対回転角の増分と寸る。面外負方向では TB300 および TB440 はラグスクリューによるプレストレスと初期 状態における集成材と鋼管に生じている間隙の距離を考慮せず，面 内方向では初期状態における集成材と鋼管に生じている間隙の距離 を考慮せずに, 完全弾塑性型の $M-\theta$ 関係を設定する。

\section{2. 面外負方向での TB300, TB440 の回転剛性や曲げ耐力の算出}

面外負方向では上端のラグスクリューの引抜による抵抗力 $\Delta P_{l t . t i}$ は式(129), 上端のラグスクリューのせん断による抵抗力 $\Delta P_{l s . t}$ は式 (130), 上端のフランジによる集成材へのめり込みによる抵抗力 $\Delta P_{\text {te. } . t i}$ は式(131), 上端のフランジと集成材間に働くフランジと集 成材の接触部分における摩擦力 $\Delta P_{\text {tef } . x . t i}$ は式(132), 繊維直交方向に
生じる六角ボルトのめり込みによる抵抗力 $\Delta P_{h e . y}$ は式(133), 繊維 方向に生じる六角ボルトのめり込みによる抵抗力 $\Delta P_{h e . x}$ は式(134), 纎維方向に生じる鋼管の集成材へのめり込みによる抵抗力 $\Delta P_{t e . x}{ }^{3)}$ は式(135), 繊維直交方向に生じる集成材と鋼管面に働く摩擦力 $\Delta P_{\text {tef. } y}$ は式(136)とする。

$\Delta P_{l t . t i}=\sum_{i} K_{l t} n_{l t . t i} \Delta \theta\left(L-X_{n}-X_{l t . t i}\right) \quad$ (129), $\Delta P_{l s . t}=K_{l s . h} n_{l s . t} \Delta \theta Y_{n}$ $\Delta P_{\text {te.y.ti }}=(1 / 2) E_{90}\left(\Delta \theta X_{n} / h\right) b X_{n} \quad(131), \Delta P_{\text {tef.x.ti }}=\Delta P_{\text {te.y.ti }} \mu$

$\Delta P_{h e . y}=K_{j s . v} \Delta \theta\left(X_{n}-\alpha L\right) \quad$ (133), $\Delta P_{h e . x}=K_{j s . h} \Delta \theta\left(h / 2-Y_{n}\right)$ $\Delta P_{\text {te.x }}=(1 / 2)\left(h-Y_{n}\right)^{2} b_{1} k_{0 c} \Delta \theta \quad(135), \Delta P_{\text {tef. } y}=\Delta P_{\text {te. } x} \mu$

TB300 および TB440 は同じ抵抗メカニズムを有するものとし, 例として Fig. 3 (a-1)，(a-2)に示す TB300 の抵抗メカニズムを基に面 外負方向の $K_{\theta}, M_{y}$ および $M_{u}$ 等を求める。 $K_{\theta}$ 算出時は Fig. 3 (a1)に示す繊維直交方向に生じる力の釣り合いによる式(137)および Fig. 3 (a-2)に示寸繊維方向に生じる力の釣り合いによる式(138)より 中立軸位置 $X_{n}$ および $Y_{n}$ を求める。これらは $X_{n}$ および $Y_{n}$ に関す る 2 元 3 次連立方程式となるため, 収斂計算を用いる必要がある。 $\Delta P_{y}=\Delta P_{\text {lt.ti }}-\left(\Delta P_{\text {te.y.ti }}+\Delta P_{\text {he.y }}+\Delta P_{\text {tef. } y}\right)=0$ $\Delta P_{x}=\Delta P_{\text {tef.x.ti }}+\Delta P_{\text {ls.t. }}-\left(\Delta P_{\text {te.x }}+\Delta P_{\text {he. } x}\right)=0$

式(137), (138)の解である $X_{n}$ および $Y_{n}$ を用いて, 繊維直交方 向に生じる力に起因する回転剛性 $K_{\theta . v}$ は式(139), 繊維方向に生じ る力に起因する回転剛性 $K_{\theta . h}$ は式(140), $K_{\theta}$ は式(141)より求める。 各抵抗力は $\Delta \theta$ を除した值とする。

$K_{\theta . v}=\Delta P_{l t . t i}\left(L-X_{n}-X_{l t . t i}\right)$

$$
+\Delta P_{\text {he. } y}\left(X_{n}-\alpha L\right)+\Delta P_{\text {te. } y . t i}(2 / 3) X_{n}+\Delta P_{\text {tef. } y} X_{n}
$$

$K_{\theta . h}=\Delta P_{\text {tef.x.ti }} Y_{n}+\Delta P_{\text {ls.t }} Y_{n}+\Delta P_{\text {te. } x} \frac{2}{3}\left(h-Y_{n}\right)+\Delta P_{\text {he. } x}\left(\frac{h}{2}-Y_{n}\right)$

$K_{\theta}=K_{\theta . v}+K_{\theta . h}$

$M_{y}$ はラグスクリューの引抜, ラグスクリューのせん断および集 成材のめり込みによる降伏のいずれか $\left(\theta_{\text {y.lt.t }}, \theta_{y . l \text { ls.t }}, \theta_{\text {y.te.ti }}\right)$ で決ま るとし, 式(142)より, 降伏回転角 $\theta_{y}$ は式(143)より求める。

$M_{y}=K_{\theta} \theta_{y} \quad$ (142), $\theta_{y}=\min \left(\theta_{y . l t . t}, \theta_{y . l s . t}, \theta_{y . t e . t i}\right)$

$\theta_{\text {y.l.t. }}=\delta_{\text {y.lt }} /\left\{L-X_{n}-\min \left(X_{l t . t i}\right)\right\}$

$\theta_{y . l s . t}=\delta_{y . l s} / Y_{n}$

(145), $\theta_{\text {y.te.ti }}=\varepsilon_{y .90} h / X_{n}$ ただし $\delta_{y . l}$ はラグスクリューの引抜による降伏変位（付録 A)， $\delta_{y . l s}$ はラグスクリューのせん断による降伏変位（付録 A）である。

$M_{u}$ はラグスクリューの引抜およびラグスクリューのせん断によ る終局のいずれか $\left(\theta_{u . l t . t}, \theta_{u . l s . t}\right)$ で決まるとし, 式(147)より, 終局到 達時回転角 $\theta_{u}$ は式(148)より求める。

$M_{u}=K_{\theta} \theta_{u} \quad$ (147), $\theta_{u}=\min \left(\theta_{\text {u.l.t. }}, \theta_{\text {u.ls.t }}\right)$ $\theta_{u . l t . t}=\delta_{u . l t} /\left\{L-X_{n}-\min \left(X_{\text {lt.ti }}\right)\right\} \quad$ (149), $\theta_{\text {u.ls.t }}=\delta_{\text {u.ls }} / Y_{n}$ ただし $\delta_{u . l t}$ はラグスクリューの引抜による終局変位（付録 $\mathrm{A} ）$, $\delta_{u . l s}$ はラグスクリューのせん断による終局変位（付録 A）である。 3. 3. 面内方向での TB300, TB440, HB の回転剛性や曲げ耐力の算出 面内方向では六角ボルトを境に内側のラグスクリューにおける繊 維直交方向のせん断による抵抗力 $\Delta P_{l s . y . i i}$ は式(151), 外側のラグス クリューにおける繊維直交方向のせん断による抵抗力 $\Delta P_{l s . y . o i}$ は式 (152)，上段のラグスクリューにおける䋊維方向のせん断による抵 抗力 $\Delta P_{l s . x . t}$ は式(153), 下段のラグスクリューにおける纎維方向に おけるせん断による抵抗力 $\Delta P_{l s . x . l}$ は式(154), 䋊維方向に生じる鋼 
管の集成材へのめり込みによる抵抗力 $\left.\Delta P_{t e . x}{ }^{3}\right)$ は式(155), 繊維直交 方向に生じる集成材と鋼管面に働く摩擦力 $\Delta P_{\text {tef. } y}$ は式(156) とする。 $\Delta P_{l s . y . i i}=\sum K_{l s . v} n_{l s . i i} \Delta \theta\left(X_{n}-X_{l s . i i}\right)$

$\Delta P_{l s . y . o i}=\sum_{i} K_{l s . v} n_{l s . o i} \Delta \theta\left(L-X_{n}-X_{l s . o i}\right)$

$\Delta P_{l s . x . t}=\sum_{i} K_{l s . h} n_{l s . t i} \Delta \theta\left(Y_{n}-Y_{l s . t i}\right)$

$\Delta P_{l s . x . l}=\sum_{i} K_{l s . h} n_{l s . l i} \Delta \theta\left(b_{0}-Y_{n}-Y_{l s . l i}\right)$

$\Delta P_{\text {te. } x}=(1 / 2)\left(b_{0}-Y_{n}-b_{2}\right)^{2} h k_{0 c} \Delta \theta \quad$ (155), $\Delta P_{\text {tef. } y}=\Delta P_{\text {te. } x} \mu$

TB300，TB440 および HB は同じ抵抗メカニズムを有するものと し, 例として Fig. 3(b-1)，(b-2)に示す TB300の抵抗メカニズムを基 に面内方向の $K_{\theta}, M_{y}$ および $M_{u}$ 等を求める。3.2. 節の評価方法と 同様に, $K_{\theta}$ 算出時は Fig. 3 (b-1)に示寸繊維直交方向に生じる力の 釣り合いによる式(157)および Fig. 3 (b-2)に示寸繊維方向に生じる力 の釣り合いによる式(158)より $X_{n}$ および $Y_{n}$ を求める。これらは $X_{n}$ および $Y_{n}$ に関する 2 元 3 次連立方程式になる。

$\Delta P_{y}=\Delta P_{l s . o}-\left(\Delta P_{l s . i}+\Delta P_{\text {tef.y }}\right)=0$

$\Delta P_{x}=\Delta P_{l s . t}-\left(\Delta P_{l s . l}+\Delta P_{t e . x}\right)=0$

式(157), (158)の解である $X_{n}$ および $Y_{n}$ を用いて, $K_{\theta . v}$ は式 (159), $K_{\theta . h}$ は式(160)より求める。 $K_{\theta}$ は式(161)上り求める。各抵 抗力は $\Delta \theta$ を除した值とする。 $K_{\theta}$ は曲げによる寄与を Fig. 4 に示 すように考慮する。

$$
\begin{aligned}
& K_{\theta . v}=\Delta P_{l s . i}\left(X_{n}-X_{l s . i i}\right)+\Delta P_{l s . o}\left(L-X_{n}-X_{l s . o i}\right)+\Delta P_{t e f . y} X_{n} \\
& K_{\theta . h}=\Delta P_{l s . t}\left(b-Y_{n}-Y_{l s . t i}\right)+\Delta P_{l s . l}\left(Y_{n}-Y_{l s . l i}\right) \\
& +\Delta P_{\text {te.x }}(2 / 3)\left(b_{0}-Y_{n}-b_{2}\right)
\end{aligned}
$$

$K_{\theta}=1 /\left[1 /\left(K_{\theta . v}+K_{\theta . h}\right)+1 /\left\{E_{0} b^{3} h /(4 L)\right\}+1 /\left\{\left(E_{0} / 15\right) b h L\right\}\right]$

$M_{y}$ は六角ボルトを境に内側および外側の上下段のラグスクリュ 一のせん断による降伏のいずれか $\left(\theta_{y . l s . i}, \theta_{y . l s . o}, \theta_{y . l s . t}, \theta_{y . l s . l}\right)$ で決 まるとし，式(162)より， $\theta_{y}$ は式(163)より求める。

$M_{y}=K_{\theta} \theta_{y} \quad$ (162), $\theta_{y}=\min \left(\theta_{y . l s . i}, \theta_{y . l s . o}, \theta_{y . l s . t}, \theta_{y . l s . l}\right)$

$\theta_{y . l s . i}=\delta_{y . l s} /\left\{X_{n}-\min \left(X_{l s . i i}\right)\right\}$

$\theta_{\text {y.ls.o }}=\delta_{\text {y.ls }} /\left\{L-X_{n}-\min \left(X_{l s . o i}\right)\right\}$

$\theta_{y . l s . t}=\delta_{y . l s} /\left(b-Y_{n}-Y_{l s . t i}\right) \quad(166), \theta_{y . l s . l}=\delta_{y . l s} /\left(Y_{n}-Y_{l s . l i}\right)$

$M_{u}$ は六角ボルトを境に内側および外側の上下段のラグスクリュ 一のせん断による終局のいずれか $\left(\theta_{\text {u.ls.i }}, \theta_{\text {u.ls.o }}, \theta_{\text {u.ls.t }}, \theta_{\text {u.ls.l }}\right)$ で決ま るとし，式(168)より， $\theta_{u}$ は式(169)より求める。

$M_{u}=K_{\theta} \theta_{u} \quad(168), \theta_{u}=\min \left(\theta_{u . l s . i}, \theta_{u . l s . o}, \theta_{u l l s . t}, \theta_{u . l s . l}\right)$

$\theta_{u . l s . i}=\frac{\delta_{u . l s}}{X_{n}-\min \left(X_{l s . i i}\right)}$

(170), $\theta_{\text {u.ls.o }}=\frac{\delta_{\text {u.ls }}}{L-X_{n}-\min \left(X_{\text {ls.oi }}\right)}$

$\theta_{u . l s . t}=\delta_{u . l s} /\left(b-Y_{n}-Y_{l s . t i}\right)$

(172), $\theta_{u . l s . l}=\delta_{u . l s} /\left(Y_{n}-Y_{l s . l i}\right)$

\section{4. 接合部の回転剛性や曲げ耐力の簡易的な評価手法の提案}

\section{1. 簡易的な評価モデルの構築}

3 章では Fig. 3 に示すように，面外負方向および面内方向の曲げ に対する接合部に $M$ が作用した時の様々な抵抗力を想定し, 各抵 抗力より繊維直交方向および繊維方向における $X_{n}$ および $Y_{n}$ を収 斂計算より求め, $K_{\theta}, M_{y}$ および $M_{u}$ 等の算出を試みた。しかし， 実務での利用を想定し弾性範囲に留めることを前提とした場合，初 期剛性と弾性限界点のみが必要であり $M-\theta$ 関係を詳細に追跡する
必要はない。本章では 3 章で提案した評価の中での $X_{n}$ および $Y_{n}$ を 手計算で簡易的に算出するために収斂計算が必要となる $X_{n}$ および $Y_{n}$ の導出過程等を省略し, 想定した同抵抗メカニズムでの接合部 内で繊維直交方向および繊維方向に発生する内部応力のうち，卓越 する抵抗力のみを考慮することで評価を試みる。これは付録 $\mathrm{B}$ に示 すように $\theta$ の増加に伴う $X_{n}$ の変動が小さく, $X_{n}$ の多少の誤差が $M-\theta$ 関係に大きな影響を及ぼさないという前提に拠っている。

\section{2. 面外負方向での TB300, TB440 の回転剛性や曲げ耐力の算出}

Fig. 3 (b-1)，(b-2)に示す抵抗メカニズムを基に TB300 および TB440の面外負方向の $K_{\theta}, M_{y}$ および $M_{u}$ 等を求める。 $K_{\theta}$ 算出時 の $X_{n}$ および $Y_{n}$ は接合部のラップ長および材せいの中間を回転中 心であると仮定し， $X_{n}$ は式(174)， $Y_{n}$ は式(175)より求める。

$$
X_{n}=L / 2 \quad \text { (174), } Y_{n}=h / 2
$$

式(174)による $X_{n}$ および式(175)による $Y_{n}$ を用いて， $K_{\theta . v}$ は式 (176), $K_{\theta . h}$ は式(177), $K_{\theta}$ は式(141)より求める。抵抗力は $\Delta P_{l t . t i}$ (式(129)), $\Delta P_{l s . t}$ (式(130)), $\Delta P_{\text {te.y.ti }}$ (式(131)), $\Delta P_{t e . x}{ }^{3)}$ （式 (135)）のみ考慮し，各抵抗力は $\Delta \theta$ を除した值とする。

$K_{\theta . v}=\Delta P_{l t . t i}\left(L-X_{n}-X_{l t . t i}\right)+\Delta P_{t e . y . t i}(2 / 3) X_{n}$

$K_{\theta . h}=\Delta P_{l s . t} Y_{n}+\Delta P_{t e . x}(2 / 3)\left(h-Y_{n}\right)$

$M_{y}$ はラグスクリューの引抜による降伏 $\left(\theta_{y . l t . t}\right)$ で決まるとし, 式 (142)より， $\theta_{y}$ は式(144)より求める。 $M_{u}$ はラグスクリューの引抜 $\left(\theta_{u . l t . t}\right)$ で決まるとし式(147)より， $\theta_{u}$ は式(149)より求める。

\section{3. 面内方向での TB300, TB440, HB の回転剛性や曲げ耐力の算出}

Fig. 3 (b-1)，(b-2)に示す抵抗メカニズムを基に TB300，TB440 お よび $\mathrm{HB}$ の面内方向の $K_{\theta}, M_{y}$ および $M_{u}$ 等を求める。4.2.節の評 価手法と同様に, $K_{\theta}$ 算出時の $X_{n}$ および $Y_{n}$ は接合部のラップ長 および材せいの中間を回転中心であると仮定するため, $X_{n}$ は式 (174), $Y_{n}$ は式(178)より求める。

$Y_{n}=b / 2$

式(174)による $X_{n}$ および式(178)による $Y_{n}$ を用いて， $K_{\theta . v}$ は式 (179), $K_{\theta . h}$ は式(180), $K_{\theta}$ は式(161)より求める。抵抗力は $\Delta P_{l s . y . i i}$ （式(151)）, $\Delta P_{l s . y . o i}$ (式(152)）, $\Delta P_{l s . x . t}$ （式(153)）, $\Delta P_{l s . x . l}$ （式(154)）のみ考慮し, 各抵抗力は $\Delta \theta$ を除した值とする。 $K_{\theta}$ は曲げによる寄与を Fig. 4 に示すように考慮する。

$K_{\theta . v}=\Delta P_{l s . i}\left(X_{n}-X_{l s . i i}\right)+\Delta P_{l s . o}\left(L-X_{n}-X_{l s . o i}\right)$

$K_{\theta . h}=\Delta P_{l s . t}\left(b-Y_{n}-Y_{l s . t i}\right)+\Delta P_{l s . l}\left(Y_{n}-Y_{l s . l i}\right)$

$M_{y}$ は六角ボルトを境に内側および外側のラグスクリューのせん 断による降伏のいずれか $\left(\theta_{y . l s . i}, \theta_{y . l s . o}\right)$ で決まるとし，式(162)より， $\theta_{y}$ は式(181)より求める。 $M_{u}$ は六角ボルトを境に内側および外側 のラグスクリューのせん断による降伏のいずれか $\left(\theta_{u . l s . i}, \theta_{u . l s . o}\right)$ で 決まるとし式(168)より， $\theta_{u}$ は式(182)より求める。

$\theta_{y}=\min \left(\theta_{y . l s . i}, \theta_{\text {y.ls.o }}\right) \quad(181), \theta_{u}=\min \left(\theta_{u . l s . i}, \theta_{\text {u.ls.o }}\right)$

\section{5. 面外負方向および面内方向に対する接合部曲げ実験}

提案した木鋼シェル用接合部 ${ }^{1)}$ の実大曲げ実験を実施し，面外負 方向および面内方向の曲げに対する回転剛性，曲げ而力および破壊 形式を確認すると共に，2 章での詳細解析および 3 章，4 章での各 評価方法との比較を行う。試験体は Fig. 2 に示す 3 種の接合部とし, TB300 および TB440 は面外負方向，TB300，TB440 および HB は面 内方向に対する各性能を確認する。Table 1 に Fig. 5 に示すセットア 
ップによる別途材料試験により求めた構成材料である集成材および 鋼材 ${ }^{1)}$ の特性值を示す。Table 1 に示寸集成材の曲げヤング率，曲げ 耐力, 含水率および比重は平均值とする。集成材は対称異等級構成 とし，樹種はベイマッ，等級はE105-F300 とする。各仕様について， 試験体は 3 体ずつとした。

\section{1. 計測計画}

ラップ内での集成材と鋼材に生じる回転角 $\theta$ は TB300 の南東側 接合部を例として Fig. 6 に示寸測定位置において矢印で表した変位 計により計測する。接合部に作用する曲げモーメント $M$ は式(183), 面外負方向での回転角 $\theta_{\text {se.out }}$ は式(184), 面内方向での回転角 $\theta_{\text {se.in }}$ は式(185), 面外負方向での中立軸 $X_{n . \text { out }}$ は式(186), 面内方向での 中立軸 $X_{n . i n}$ は式(187) とする。

$M=(P / 2) a$ (183), $\theta_{\text {se.out }}=\left(\delta_{2}-\delta_{1}\right) / L$

$\theta_{\text {se.in }}=\left\{\left(\delta_{5}-\delta_{6}\right)+\left(\delta_{8}-\delta_{7}\right)\right\} /(2 L)$

$X_{\text {n.out }}=\left\{\left(-\delta_{1}\right) /\left(\delta_{2}-\delta_{1}\right)\right\} L$

$X_{\text {n.in }}=\left\{\delta_{5} /\left(\delta_{5}-\delta_{6}\right)+\left(-\delta_{7}\right) /\left(\delta_{8}-\delta_{7}\right)\right\}(L / 2)(187), \quad a=780(\mathrm{~mm})$ (188) ただし， $P$ はアムスラーの荷重， $a$ は支点と荷重点間距離， $\delta_{1}$ お よび $\delta_{2}$ は面外方向変位, $\delta_{3}$ および $\delta_{4}$ は面内方向での水平変位, $\delta_{5}, \delta_{6}, \delta_{7}$ および $\delta_{8}$ は面内方向での鉛直変位である。

\section{2. 載荷計画}

Fig. 5 に実験のセットアップを示す。実験装置はアムスラー試験 機, 加力梁および加力治具で構成され, 試験体はアムスラーのラム に取り付けられている反力治具により両端単純支持の状態にする。 載荷は 4 点荷重法により行い, アムスラーのクロスヘッドに装着し た加力梁を介して接合部の両端を鉛直方向に強制変位させ，接合部 に等曲げモーメントを加える。載荷速度が一定となるようにアムス ラーのラムを上昇させていき, 荷重が最大值に到達した後に最大荷 重の 8 割以下に低下した時点で載荷を終了する。

\section{3. 実験結果}

Fig. 7 に各試験体の $M-\theta$ 関係および破壊状況を示す。同図には 2 章での詳細解析結果および 3 章, 4 章での各評価值を併せて示す。 評価值は Table 1 に示寸曲げヤング率を用いる。

面外負方向では割裂発生により一時的な耐力低下を繰り返し経験 するものの, 変形と共に耐力は増加し続けた。破壊形式はフランジ 端部におけるラグスクリューの引抜およびラグスクリューの先端位 置における集成材の割裂である。その後の大変形域では割裂の拡大 がフランジ端部の集成材のせん断破壊を誘発し, 曲げ耐力が最大曲 げ而力の 8 割以下に低下した際の破壊形式はラグスクリュー先端周 辺での集成材の割裂拡大およびフランジ端部の集成材のせん断破壊 であった。TB300 は変形の増加と共に耐力は最大荷重付近を維持す る傾向があり，延性的な破壊を示した。TB440 は破壊と共に急激な 耐力低下を経験し, 耐力低下後の耐力増加は見込めない傾向があり, 脆性的な破壊を示した。面内方向ではラグスクリューによる割裂が 発生し, 変形が進むにつれて割裂の拡大が確認できた。破壊形式は ラグスクリューによる集成材の割裂である。その後の大変形域では 主に下列のラグスクリューによる割裂の拡大が顕著となり，曲げ耐 力が最大曲げ耐力の 8 割以下に低下した際の破壊形式も同様にラグ スクリューによる割裂の拡大である。また, TB300 はラグスクリュ 一を片側からのみ打ち込み, HB はラグスクリューを両側から打ち 込んでいるため, TB300 は HB に比べラグスクリューによる集成材
Table 1 Characteristic values of constituent materials (a) Glued laminated timber

\begin{tabular}{|c|c|c|c|c|c|c|c|}
\hline \multirow{2}{*}{$\begin{array}{c}\text { Tree } \\
\text { species }\end{array}$} & Composition & $\begin{array}{c}\text { Strength } \\
\text { grade }\end{array}$ & Direction & $\begin{array}{c}\text { Bending } \\
\text { Young's } \\
\text { modulus } \\
\left(\mathrm{kN} / \mathrm{mm}^{2}\right)\end{array}$ & $\begin{array}{c}\text { Bending } \\
\text { strength } \\
\left(\mathrm{N} / \mathrm{mm}^{2}\right)\end{array}$ & $\begin{array}{c}\text { Moisture } \\
\text { content } \\
(\%)\end{array}$ & $\begin{array}{c}\text { Specific } \\
\text { gravity } \\
(-)\end{array}$ \\
\hline Douglas fir & $\begin{array}{c}\text { Specific } \\
\text { symmetric }\end{array}$ & E105-F300 & $\begin{array}{c}\text { Out-of- } \\
\text { plane }\end{array}$ & 16.9 & 64.2 & \multirow{2}{*}{9.94} & 0.55 \\
\cline { 4 - 6 } & In-plane & 15.2 & 48.9 & 9.94 \\
\hline
\end{tabular}

(b) Steel connection

\begin{tabular}{|c|c|c|c|c|c|c|}
\hline Part & Steel grade & $\begin{array}{c}\text { Young's } \\
\text { modulus } \\
\left(\mathrm{kN} / \mathrm{mm}^{2}\right)\end{array}$ & $\begin{array}{c}\text { Yield } \\
\text { strength } \\
\left(\mathrm{N} / \mathrm{mm}^{2}\right)\end{array}$ & $\begin{array}{l}\text { Tensile } \\
\text { strength } \\
\left(\mathrm{N} / \mathrm{mm}^{2}\right)\end{array}$ & $\begin{array}{c}\text { Yield strain } \\
(\%)\end{array}$ & $\begin{array}{c}\text { Rupture } \\
\text { elongation } \\
(\%)\end{array}$ \\
\hline Web & \multirow{2}{*}{ SM490A } & \multirow{2}{*}{$2.09 \times 10^{2}$} & \multirow{2}{*}{346} & \multirow{2}{*}{511} & \multirow{2}{*}{0.17} & \multirow{2}{*}{39.9} \\
\hline Flange & & & & & & \\
\hline
\end{tabular}
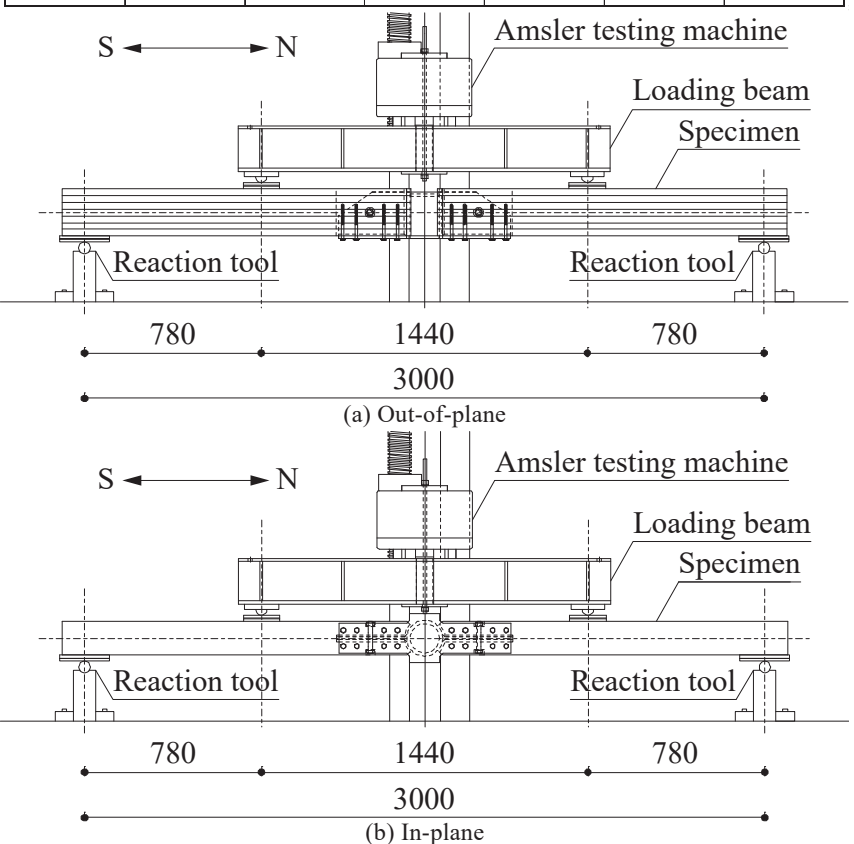

Fig. 5 Setup of connection bending test

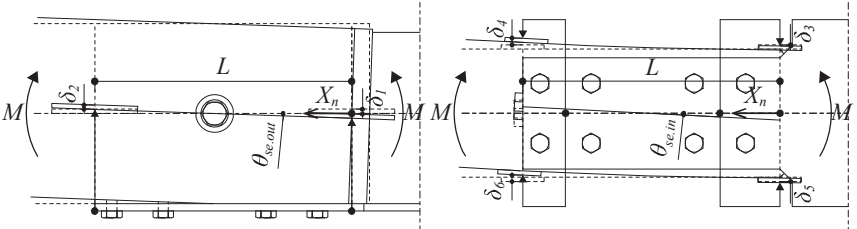

(a) Out-of-plane

Fig. 6

(b) In-plane

のせん断破壊が発生しにくく，変形性能が期待できる。

Table 2 に実験で得られた各試験体の回転剛性の平均值 $K_{\theta}, K_{\theta}$ の信頼水準 $75 \%$ の $50 \%$ 下限值 $K_{\theta .50 \%}, K_{\theta}$ より求めた無次元化回転 剛性 $\kappa$ および接合部の剛接度による座屈荷重低減係数 $\beta(\kappa)$ を示す。 1 試験体に接合部が 2 か所あり, 試験体数は 3 のため, 標本数は 6 とする。 $K_{\theta}$ は文献 6$), \kappa$ および $\beta(\kappa)$ は文献 9)を参照し, 式(189), (190)より求める。

$\kappa=\frac{K_{\theta} l}{E_{0} I} \quad(189), \beta(\kappa)=\left\{\begin{array}{lll}0.47 \log _{10}(\kappa)+0.34 & (1 \leq \kappa \leq 10 & \text { : 低剛性 }) \\ 0.19 \log _{10}(\kappa)+0.62 & (10 \leq \kappa \leq 100 & \text { :中剛性) }(190) \\ 1.0 & (100 \leq \kappa & \text { :高剛性 })\end{array}\right.$ ただし $l$ は部材長， $E_{0}$ は格子部材である集成材のヤング率， $I$ は 断面二次モーメントである。

面外負方向の場合, TB300 と TB440の $K_{\theta}$ は同程度の值を示した が，TB440 は TB300 と比べるとばらつきが大きいため， $K_{\theta .50 \%}$ で 
は TB440 は TB300 よりも下回り, 面内方向の場合, HB の $K_{\theta}$ は $\mathrm{TB} 300$ に比べ 2 倍程度の值を示した。HB は TB300 に比べてラグス クリューの長さは短いものの, 集成材の両側から施し, 本数は多い ためであると考えられる。ばらつきは各接合部共に小さい。面外負 方向に対する $K_{\theta}$ は共に $\kappa=11$ 程度と中剛性接合部と評価される。

Table 3 に 3 体の最大曲げ耐力の平均值 $M_{\max }, M_{\max }$ の信頼水準 $75 \%$ の $5 \%$ 下限值 $M_{\max .5 \%}$ および Table 1 に示寸曲げ強度より求めた 集成材曲代耐力 $M_{b}$ に対する $M_{\text {max }}$ の比率 $M_{\text {max }} / M_{b}$ を示す。標本 数は試験体数と同じ 3 とする。面外負方向の場合, TB440 は TB300 に比べ $M_{\max }$ が上回る值を示したが，TB440 は TB300 に比べてばら つきが大きいため $M_{\max .5 \%}$ では TB440 は TB300 よりも下回る值を 示した。面内方向の場合, HB は TB300 に比べ $M_{\max }$ が上回る值を 示し, ばらつきは各接合部共に小さい。また，面外負方向では面内 方向の $M_{\max }$ に比べて 2.4〜2.7 倍程度の值を示した。

面外負方向の場合は繊維方向の鋼管による集成材の木口へのめり 込みによる抵抗が大きく働き，かつラップ内における集成材の曲げ およびせん断変形が生じやすいため, ラップ長に対して回転剛性お よび曲げ耐力は比例的な関係を示さないことが確認できる。また, TB300に比べTB440では集成材が曲げおよびせん断変形しやすく, フランジと集成材の離間が進み，ラグスクリューの引抜および集成 材の割裂が早期に現れたため，TB440 では TB300 よりも鋼材に対 する木口での回転は進まず，繊維方向の鋼管による集成材の木口へ のめり込みによる抵抗があまり働かない。そのため, TB300 では繊 維直交方向と繊維方向の抵抗がバランスよく働いたが, TB440では 繊維直交方向の抵抗が卓越し，回転剛性および曲げ耐力は同程度の 值を示したと考えられる。面内方向の場合はラグスクリューのせん 断による抵抗が主に働いたため, 回転剛性および曲げ耐力は TB 300 に比べて TB440 および HB の方が高い值を示した。TB440 はラップ 長が長いため, ラップ内でのラグスクリューのせん断による抵抗力 が高まり，HB はラグスクリューの長さが TB300 に比べて短いもの の, 打ち込み本数が多いため, 接合部全体のラグスクリューのせん 断による抵抗力が高く見込めるためであると考えられる。また， Fig. 7 (b)に示寸面外負方向の TB440 および Fig. 7 (c) に示す面内方向 の TB300の $M-\theta$ 関係に見られるようにスリップのような挙動を示 寸試験体が確認された。これは試験体の施工上のガタによるもので あり，スリップした試験体では鋼管と集成材の木口間に大きな間隙 が確認された。間隙により繊維方向の鋼管による集成材の木口への めり込みによる抵抗が効率良く働かなかったと考えられる。

面外負方向および面内方向共に 2 章で提案した解析值は実験值を 概ね捉えており，3 章および 4 章で提案した評価值でも実験值を安 全側に評価している。面外負方向の場合, 実験では割裂が生じ始め てから TB300は $M-\theta$ 関係の勾配が緩やかになり始め, TB440 は急 激な耐力低下を示している。2 章の解析值は割裂が生じるまでは傾 向を捉えているものの $\theta$ が増すと共に $M$ は上昇し続けている。こ れは割裂が生じた点以降では集成材の平面保持の仮定が成立しなく なるためであると考えられ, 提案した解析による評価手法は割裂発 生までの確認に留める必要がある。面内方向の場合, 実験では割裂 が生じ始めてから各接合部共に $M-\theta$ 関係の勾配が緩やかになり始 めている。解析では TB300 および HB は割裂が生じるまでは傾向を 捉えているものの, TB440 は曲壮剛性が低く, 式(91)右辺第 2 項が
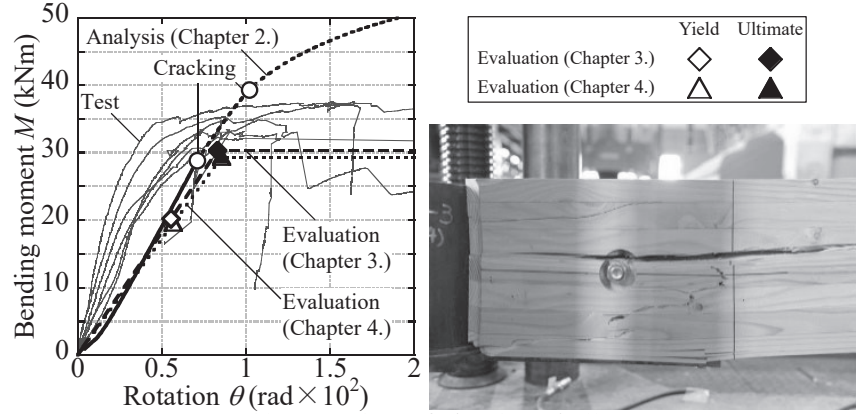

(a) TB300 (Out-of-plane(negative))

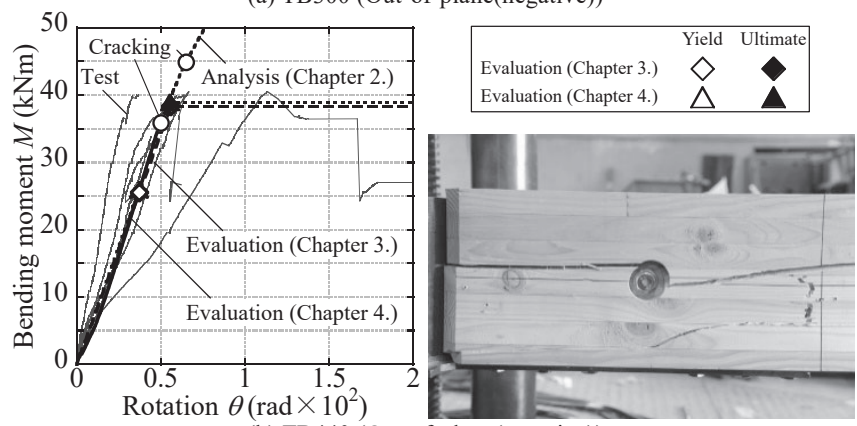

(b) TB440 (Out-of-plane(negative))

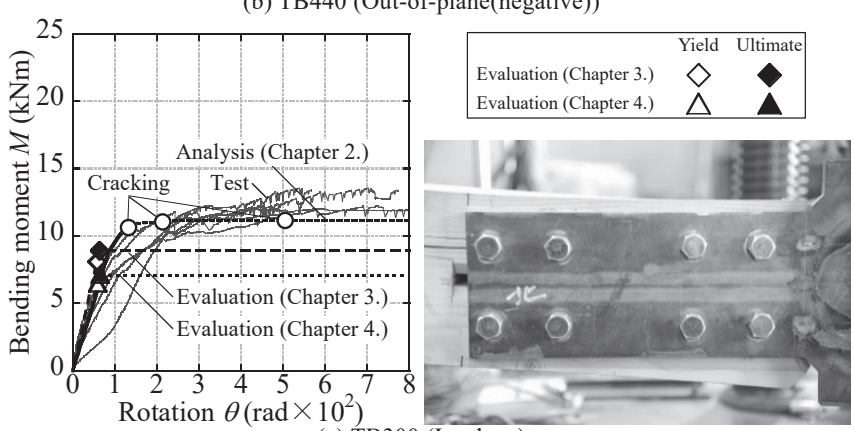

(c) TB300 (In-plane)
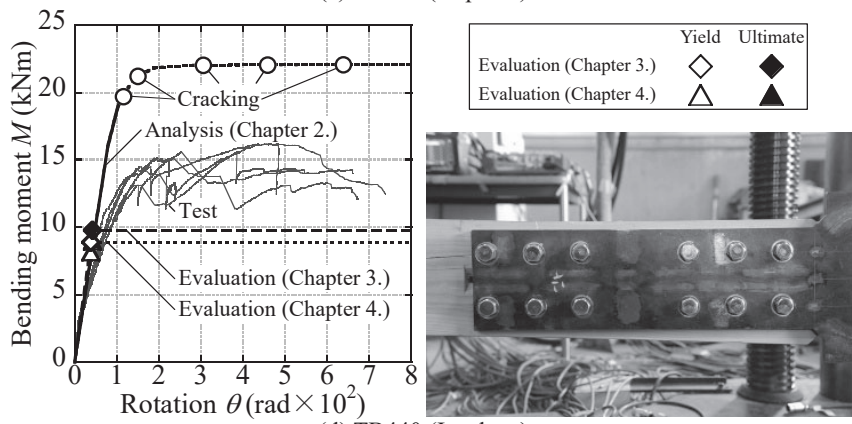

(d) TB440 (In-plane)

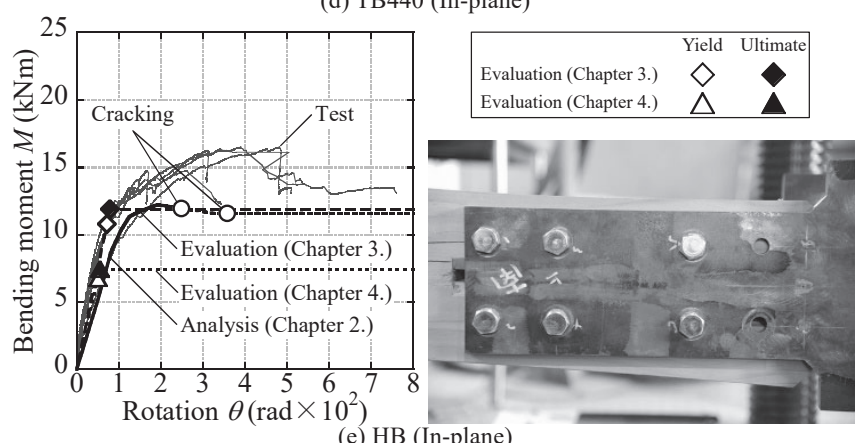

(e) HB (In-plane)

Fig. $7 \quad M-\theta$ relationship and failure pattern in each specimen

卓越するが，簡易評価手法は適合条件を満たさないため，割裂発生 点の精度が低下寸る。一方で $\mathrm{TB} 300$ および $\mathrm{HB}$ では割裂の評価も行 えている。 
Fig. 8 に各接合部の面外正 ${ }^{1)}$, 面外負および面内方向に対する $M$ $\theta$ 関係の比較を示す。面外正方向に比べて面外負方向では TB300 の回転剛性は 1.2 倍, 曲げ耐力は 2.7 倍程度高く, TB440 の回転剛 性は 0.7 倍と低いものの曲げ耐力は 1.8 倍程度高い。面外正方向で は繊維方向の鋼管による集成材の木口へのめり込みによる抵抗が見 込めず，面外負方向では見込めるためである。また，面外正方向に 対して面外負方向ではばらつきが見られるが, 面外負方向では繊維 方向の鋼管による集成材の木口へのめり込みによる抵抗の寄与率が 高く, 施工上のガタによる鋼管と集成材の木口間の間隙の影響を受 けや寸いためである。面外正方向に比べて面内方向では TB300 の 回転剛性は 0.1 倍, 曲げ耐力は 1.0 倍, TB 440 の回転剛性は 0.1 倍, 曲げ耐力は 0.8 倍, $\mathrm{HB}$ の回転剛性は 0.3 倍, 曲げ耐力は 0.5 倍程度 低い。集成材のスリットとウェブの隙間によりウェブによる集成材 へのめり込みによる抵抗力は無視できるほど小さいため, 回転剛性 および曲げ耐力は低い值を示したと考えられる。

木鋼シェルの座屈荷重を評価する際, 面外方向の回転剛性に TB300 は面外正方向, TB440 は面外負方向の回転剛性を採用寸るこ とで安全側に評価可能である。また，面外方向に対して面内方向は 回転剛性および曲げ耐力が顕著に低いため, 面内方向の回転剛性を 考慮した座屈荷重の評価を行う必要がある。

\section{6. 結}

木鋼ハイブリッド単層直交格子ラチスシェル用接合部 ${ }^{1)}$ の面外負 方向および面内方向の曲げに対する回転剛性および曲げ耐力を実大 載荷実験により明らかにすると共に, 数值解析的に接合部の挙動を 再現し, 実務での利用を考慮した簡易的な評価手法を提案した。得 られた知見を以下に示す。

1) 面外負方向の場合, TB300 では回転剛性および曲げ耐力共に面 外正方向に比べて上回り，TB440 では回転剛性は下回るものの 曲げ耐力は上回ることを確認した。

2) 面内方向の場合, 各接合部共に回転剛性および曲げ而力は面外 正方向に比べて大きく下回る。TB300 に対する TB440および HB の曲げ耐力は 2 倍程度大きく, これはラグスクリューのせん断 抵抗が大きく起因していると考えられる。

3) 面外負方向および面内方向では 2 章の解析值は 5 章の実験值を 概放捉え，モデルの妥当性を示した。3 章および 4 章の評価值は 5 章の実験值を安全側に評価可能であることを確認した。

4) 面外正方向に対して面外負方向では TB300 の回転剛性および曲 げ耐力は共に高く, TB440 の回転剛性は下がるものの曲げ耐力 は高い值を示し, 面外方向に対して面内方向では各接合部共に 回転剛性および曲げ耐力は低い值を示した。木鋼シェルの座屈 荷重を評価する際，面内方向の回転剛性を考慮する必要がある。 今後, 本研究で得られた各方向の接合部特性を用い, これらが木 質単層ラチスシェル座屈耐力に与える影響について分析する。ただ し, クリープ変形の影響および耐火や結露等の建築性能の確認等に ついては今後の課題とする。

\section{謝辞}

本研究を実施するにあたりご協力を戴きました, 日建設計 : 水谷 美和氏，西本篤史氏，重松瑞樹氏に感謝いたします。
Table 2 Rotational stiffness $K_{\theta}$, normalized rotational stiffness $K$ and knock-down factor $\beta(\kappa)$

\begin{tabular}{|c|c|c|c|c|c|}
\hline Direction & \multicolumn{2}{|c|}{$\begin{array}{c}\text { Out-of-plane } \\
\text { (negative) }\end{array}$} & \multicolumn{4}{|c|}{ In-plane } \\
\hline Connections & TB300 & TB440 & TB300 & TB440 & HB \\
\hline $\begin{array}{c}\text { Average of rotational stiffness } \\
K_{\theta}(\mathrm{kNm} / \text { rad) }\end{array}$ & 7311 & 7369 & 697 & 1295 & 1438 \\
\hline $\begin{array}{c}\text { Coefficient of variation } \\
\text { of 3 samples } C V(-)\end{array}$ & 0.34 & 0.44 & 0.33 & 0.11 & 0.18 \\
\hline $\begin{array}{c}\text { Confidence level factor } k(-) \\
1-C V \cdot k(-)\end{array}$ & 0.90 & 0.87 & 0.90 & 0.97 & 0.95 \\
\hline $\begin{array}{c}50 \% \text { lower tolerance limit of } K_{\theta} \\
K_{\theta .50 \%}(\mathrm{kNm} / \text { rad) }\end{array}$ & 6575 & 6405 & 628 & 1252 & 1360 \\
\hline $\begin{array}{c}\text { Normalized rotational stiffness } \\
\text { of } K_{\theta} \kappa(-)\end{array}$ & 11.2 & 11.3 & & & \\
\hline $\begin{array}{c}\text { Knock down factor } \\
\beta(\kappa)(-)\end{array}$ & 0.82 & 0.82 & & & \\
\hline
\end{tabular}

Table 3 Maximum bending strength $M_{\max }$ and ratio against bending strength of timber $M_{\max } / M_{b}$

\begin{tabular}{|c|c|c|c|c|c|}
\hline & \multicolumn{2}{|c|}{$\begin{array}{c}\text { Out-of-plane } \\
\text { (negative) }\end{array}$} & \multicolumn{3}{|c|}{ In-plane } \\
\hline Connections & TB300 & TB440 & TB300 & TB440 & HB \\
\hline $\begin{array}{c}\text { Average of maximum } \\
\text { bending strength } M_{\max }(\mathrm{kNm})\end{array}$ & 35.3 & 38.1 & 13.0 & 15.6 & 15.8 \\
\hline $\begin{array}{c}\text { Coefficient of variation } \\
\text { of 3 samples } C V(-)\end{array}$ & 0.06 & 0.10 & 0.12 & 0.03 & 0.06 \\
\hline $\begin{array}{c}\text { Confidence level factor } k(-) \\
1-C V \cdot k(-)\end{array}$ & 0.82 & 0.69 & 0.64 & 0.89 & 0.81 \\
\hline $\begin{array}{c}5 \% \text { lower tolerance limit of } M_{\max } \\
M_{\max .5 \%}(\mathrm{kNm})\end{array}$ & 28.88 & 26.19 & 8.25 & 13.95 & 12.84 \\
\hline$M_{\max } / M_{b}(-)$ & 0.55 & 0.59 & 0.20 & 0.24 & 0.25 \\
\hline
\end{tabular}

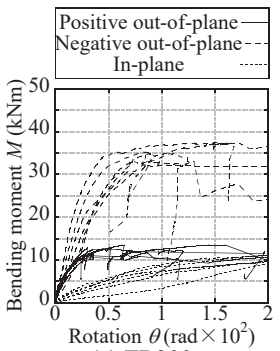

(a) TB300

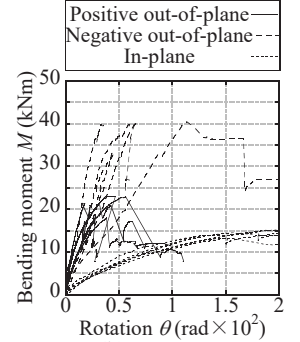

(b) TB440

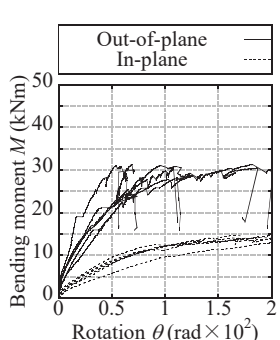

(c) HB

\section{Fig. 8 Comparison of $M-\theta$ relationship}

\section{参考文献}

1) Harada, H., Nakajima, S., Yamazaki, Y., Matsui R., Hayashi, K., Sakata, H. and Takeuchi, T.: Rotational Stiffness and Bending Strength of Steel Connections in Timber Lattice Shell, Journal of Structural and Construction Engineering (Transactions of AIJ), Vol. 83, No. 746, pp. 577-587, 2018. 4 (in Japanese) 原田公明, 中島舜, 山崎義弘, 松井良太, 林賢一, 坂田弘安, 竹内㛩：木鋼 ハイブリッドラチスシェルの接合部回転剛性および曲げ耐力, 日本建築 学会構造系論文集, 第 83 巻, 第 746 号,pp. 577-587, 2018.4

2) Sakata, H., Yamazaki, Y., Udagawa, H. and Ohashi, Y.: Experimental Study on Flexural-Shear Behavior of Mortise-Tenon Joint with Dowel, Journal of Structural and Construction Engineering (Transactions of AIJ), Vol. 77, No. 671, pp. 45-54, 2012. 1 (in Japanese)

坂田弘安, 山崎義弘, 宇田川洋隆, 大橋好光: 曲げせん断を受ける長ほぞ 差し込栓打ち接合部の力学的挙動に関する研究, 日本建築学会構造系論 文集，第 77 巻，第 671 号,pp. 45-54, 2012.1

3) Japan Housing \& Wood Technology Center: Evaluation Method and Structure Design Guide of Timber Frame Structure, 2016. 3 (in Japanese) 
日本住宅・木材技術センター: 木造ラーメンの評価方法・構造設計の手 引き, 2016. 3

4) Architectural Institute of Japan: Design Manual for Engineered Timber Joints, 2009. 11 (in Japanese)

日本建築学会: 木質構造接合部設計マニュアル, 2009. 11

5) Nakatani, M. and Komatsu, K.: Mechanism of Pull-out Performance in Lagscrewbolted Timber Joints III: Development of a Theory of Pull-Out Properties Perpendicular to the Grain, The Japan Wood Research Society, Vol. 52, No. 3, pp. 160-167, 2006. 5 (in Japanese)

中谷誠, 小松幸平: ラグスクリューボルトの引抜き性能発現機構(第 3 報): 繊維直交方向引抜き理論の構築, 木材学会誌, 第 52 巻, 第 3 号, pp. 160167, 2006. 5

6) Architectural Institute of Japan: Standard for Structural Design of Timber Structures, 2015. 11 (in Japanese)

日本建築学会: 木質構造設計規準・同解説, 2015. 11

7) Forest Research and Management Organization: Wood Industry Handbook, Maruzen Publishing Co.Ltd, 2004. 3 (in Japanese)

森林総合研究所：木材工業ハンドブック，丸善出版株式会社, 2004.3

8) Tomita, M., Nakano, Y., Sakata, H., Yamazaki, Y., Takeuchi, T., Harada, H., Matsui, R., Mizutani, M., Asahi, T. and Kadono, D.: An Experiment Study on partial Embedment of Glued Laminated Timber Perpendicular to the Grain and Reinforcement of Embedment Performance by Screw - Part 1 Outline and Experimental Results -, Summaries of Technical Papers of Annual Meeting, Architectural Institute of Japan, Structure-III, pp. 83-84, 2017. 8 (in Japanese) 冨田弥奈美, 中野佑太, 坂田弘安, 山崎義弘, 竹内徹, 原田公明, 松井良 太, 水谷美和, 朝日智生, 角野大介: 集成材のめり込み挙動とビスによる めり込み性能向上に関する実験研究 - その 1 実験概要と結果 - , 日本建 築学会大会学術講演梗概集 構造III, pp. 83-84, 2017.8

9) Architectural Institute of Japan: AIJ Recommendation for Design of Latticed Shell Roof Structures, 2016. 11 (in Japanese)

日本建築学会: ラチスシェル屋根構造設計指針, 2016. 11

10) Nakano, S., Sakata, H., Jokaku, M., Tomimoto, A. and Nakamura, Y.: Experimental Study on Mechanical Behavior of Glulam Japanese Cedar-Steel Composite Member Adopted Friction Connector: Part 6. Bending Behavior and Estimation of Bending Strength of Composite Member, Summaries of Technical Papers of Annual Meeting, Architectural Institute of Japan, C-1, Structure-III, pp. 297-298, 2008. 7 (in Japanese)

中野翔太, 坂田弘安, 上角充広, 富本淳, 中村泰教: 摩擦接合型コネクタ を用いたスギ集成材と鋼板によるハイブリッド部材の力学的挙動に関す る実験研究: その 6. 部材曲げ特性と曲げ耐力評価, 日本建築学会大会学 術講演梗概集 C-1 分冊 構造III, pp. 297-298, 2008. 7

11) Kobayashi, K. and Yasumura, M.: Influences of Number and Spacing of Fasteners on Single Shearing Properties of Steel-to-Timber Joints with Lag Screws, Journal of Structural Engineering B, Vol. 59B, pp. 537-543, 2013. 3 (in Japanese) 小林研治, 安村基: 鋼板添え板ラグスクリュー接合部の一面せん断性能 における接合具本数と配置条件の影響, 構造工学論文集 B, 第 $59 \mathrm{~B}$ 巻, pp. 537-543, 2013. 3

\section{付録 $\mathrm{A}$ 各関係式のまとめ}

本論で用いるラグスクリューによる集成材の割裂破壊に対寸る終局耐力 ${ }^{6)}$, ラグスクリューの引抜剛性, 降伏変位および終局変位 ${ }^{5)}$, ラグスクリューの せん断剛性および降伏変位 ${ }^{6}$, 六角ボルトのめり込み剛性 ${ }^{6}$ および䋊維方向 に対する集成材の面圧剛性 ${ }^{3)}$ 等の各関係式については文献 1)の付録 $\mathrm{A}$ を参照 する。その他本論で用いた各関係式を以下に示す。

1) 文献 5)によるラグスクリューの引抜降伏耐力式

ラグスクリューの引抜による降伏耐力 $P_{y l}$ は設計用許容引抜耐力とし, 式 $(\mathrm{A} 1)^{6)}$ より求める。

$P_{y l}=(1 / 3)_{j} K_{d j} K_{m} P_{u l}$

$P_{u l}= \begin{cases}\frac{f_{v 90} \pi d_{l}\left(E_{0} A_{w}+E_{s} A_{s}\right) \sinh \left(k l_{1}\right)}{k\left\{E_{s} A_{s} \cosh \left(k l_{1}\right)+E_{0} A_{w}\right\}} & \left(E_{0} A_{w} \leq E_{s} A_{s}\right) \\ \frac{f_{v 90} \pi d_{l}\left(E_{0} A_{w}+E_{s} A_{s}\right) \sinh \left(k l_{1}\right)}{k\left\{E_{0} A_{w} \cosh \left(k l_{1}\right)+E_{s} A_{s}\right\}} & \left(E_{s} A_{s} \leq E_{0} A_{w}\right)\end{cases}$

$f_{v}=5.39\left(\mathrm{~N} / \mathrm{mm}^{2}\right)$

(A3), ${ }_{j} K_{d}=2.0$

(A4), ${ }_{j} K_{m}=1.0$
ただし $f_{v}$ はせん断強さ（繊維直交方向）， ${ }_{j} K_{d}$ は荷重継続期間影響係数， ${ }_{j} K_{m}$ は含水率影響係数である。

2) 文献 6)によるラグスクリューのせん断降伏耐力および終局変位式

ラグスクリューのせん断による降伏耐力 $P_{y s}$ は式(A6)より求める。

$P_{y s}=C F_{e} d_{l} l_{2} \quad$ (A6), $C=\min \left\{1, \sqrt{2+(2 / 3) \gamma_{l}\left(d_{l} / l_{2}\right)},\left(d_{l} / l_{2}\right) \sqrt{2 / 3}\right\}$

$\gamma_{l}=F_{l} / F_{e}$

(A8), $\quad F_{l}=748\left(\mathrm{~N} / \mathrm{mm}^{2}\right)$

ただし $C$ は接合形式とその破壊形式等によって定まる接合形式係数， $F_{e}$ は 集成材の基準支圧強度， $\gamma_{l}$ はラグスクリューの基準材料強度と集成材の基 準支圧強度の比， $F_{l}$ はラグスクリューの基準材料強度 ${ }^{11)}$ である。

ラグスクリューのせん断による終局耐力 $P_{u s}$ は式(A10)より求める。

$P_{u s}=r_{u} P_{y s}$

(A10), $r_{u}=1.1$

ただし $r_{u}$ は終局強度比である。

従ってラグスクリューのせん断による終局変位 $\delta_{u . l s}$ は式(A12)より求める。 $\delta_{u . l s}=P_{u s} / K_{s}$

3) 文献 6)による六角ボルトのめり込み降伏変位および終局変位式

六角ボルトのめり込みによる降伏耐力 $P_{y . h e}$ は式(A13)より求める。

$P_{y . h e}=C F_{e} d_{b} l_{b}$

$C=\min \left\{1, \sqrt{2+(8 / 3) \gamma_{b}\left(d_{b} / l_{b}\right)^{2}}-1,\left(d_{b} / l_{b}\right) \sqrt{(8 / 3) \gamma_{b}}\right\}$

$\gamma_{b}=F_{b} / F_{e} \quad(\mathrm{~A} 15), F_{b}=400\left(\mathrm{~N} / \mathrm{mm}^{2}\right) \quad(\mathrm{A} 16), l_{b}=91(\mathrm{~mm})$

ただし $\gamma_{b}$ は六角ボルトの基準材料強度と集成材の基準支圧強度の比， $F_{b}$ は 六角ボルトの基準材料強度， $l_{b}$ は六角ボルトと集成材の接触長さである。

六角ボルトのめり込みによる終局耐力 $P_{u, h e}$ は式(A49)より求める。

$P_{u . h e}=r_{u} P_{y . h e} \quad(\mathrm{~A} 18), r_{u}= \begin{cases}1.0 & \text { (繊維方向) } \\ 1.1 & \text { (繊維直交方向) }\end{cases}$

従って六角ボルトのめり込みによる降伏変位 $\delta_{y, h e}$ は式(A20), 終局変位 $\delta_{u \cdot h e}$ は式(A21)より求める。

$\delta_{y . h e}=P_{y . h e} / K_{j s}$

(A20), $\delta_{u, h e}=P_{u, h e} / K_{j s}$

\section{付録 B 中立軸位置の推移}

Fig. B1 に TB300 の中立軸 $X_{n}$-回転角 $\theta$ 関係を示寸。同図には 2 章での解 析による評価, 3 章での収斂計算を伴う評価および 4 章での簡易的な評価の $X_{n}$ を併せて示す。回転角が小さい時はラグスクリューによるプレストレス や集成材と鋼管に生じている間隙の影響により実験值がばらつくが，回転角 が大きくなると共にラグスクリューによるプレストレスは無くなり，集成材 と鋼管に生じている間隙が埋まるため, 繊維方向の鋼管による集成材の木口 へのめり込みによる抵抗が生じ，回転中心が鋼管側に移る傾向がある。面内 方向の場合，解析值は実験值の $X_{n}$ の傾向を概ね捉えている。 $X_{n}$ が TB300 では $150 \mathrm{~mm}$ もしくは $75 \mathrm{~mm}$ 付近に収束する傾向が見られるが，ラグスクリ ユーを片側のみ打ち込んでいるため, 打ち込み側では解析と同様な抵抗メ力 ニズムを示すと考えられ, 解析值は実験值を捉えられるが, 打ち込んでいな い側ではラグスクリューのせん断による抵抗がなく主に繊維方向の鋼管によ る集成材の木口へのめり込みによる抵抗が働き，打ち込多側の回転中心より も鋼管側に回転中心が移り，実験值の $X_{n}$ が小さい值となったと考えられる。 本研究での $M-\theta$ 関係や $X_{n}$ の推移も実験結果の傾向と対応しており， $X_{n}$ の誤差は全体挙動や局所挙動にそれほど大きな影響を与えないと判断した。

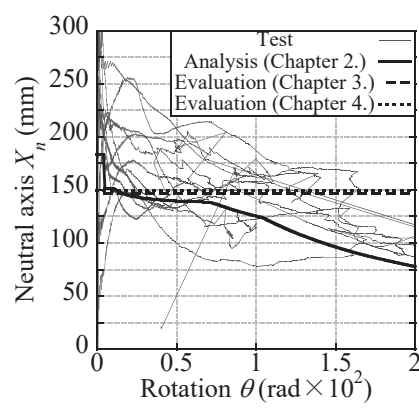

(a-1) Out-of-plane

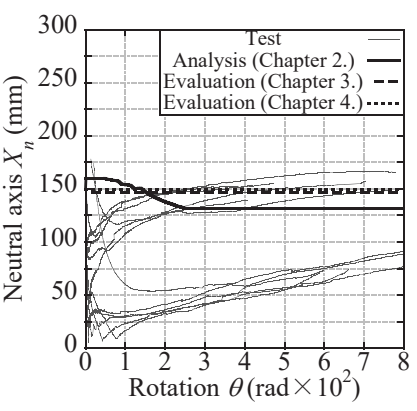

(b-1) In-plane
Fig. B1 $X_{n}-\theta$ relationship of TB300 


\title{
ROTATIONAL STIFFNESS OF STEEL CONNECTIONS FOR TIMBER LATTICE SHELL IN NEGATIVE OUT-OF-PLANE AND IN-PLANE DIRECTIONS
}

\author{
Shun NAKAJIMA *1, Yoshihiro YAMAZAKI ${ }^{* 2}$, Hiroyasu SAKATA*3, \\ Toru TAKEUCHI ${ }^{* 3}$, Hiroaki HARADA ${ }^{* 4}$ and Kenichi HAYASHI*5 \\ ${ }^{* 1}$ Former Grad. Student, Dept. of Arch. and Build. Eng., Tokyo Institute of Technology, M.Eng. (NIHON SEKKEI, INC.) \\ ${ }^{* 2}$ Assist. Prof., Dept. of Arch. and Build. Eng., Tokyo Institute of Technology, Dr.Eng. \\ ${ }^{* 3}$ Prof., Dept. of Arch. and Build. Eng., Tokyo Institute of Technology, Dr.Eng. \\ *4 NIKKEN SEKKEI, M.Eng. \\ ${ }^{*}$ Nippon Steel Engineering Co., Ltd., M.Eng.
}

The authors have proposed effective steel connections achieving high bending stiffness and strength for timber grid-shell structures in the previous research. They are composed of joints with T-section or H-section brackets connected to glued laminated timber section members through lag-screw bolts at flanges, their bending stiffness and strength have proved to be much higher than the ones of conventional connections. However, their performance against negative out-of-plane and in-plane directions which affect the shell buckling strength are not clear yet. In this research, the bending performance of the proposed connections against negative out-of-plane and in-plane directions are confirmed through real-size mock-up tests. They are compared to the performance against positive out-of-plane. Formulas for evaluating the stiffness and strength of the connections against these directions are proposed, and their validity are verified by comparing with the test results.

First, detailed analysis methods evaluating negative out-of-plane and in-plane stiffness and strength are constructed based on equilibrium of forces between steel bracket and timber beam and their compatibility condition. Next, approximating the process of neutral axis iteration, simplified formulas are demonstrated. Also, assuming the neutral axis at the center of the connections, further simplified equations for stiffness and strength are proposed. Then, real-sized mock-up specimens for the proposed connections are constructed, and simple bending tests in negative out-of-plane and in-plane directions are carried out. Their bending moment - rotational angle relationships are compared with the proposed formulas and their validity is confirmed. As results, the following conclusions are obtained.

1) TB300 (T-section bracket with $300 \mathrm{~mm}$ length) exhibited higher bending stiffness and strength in negative out-of-plane direction than those in positive direction. TB400 (T-section with $400 \mathrm{~mm}$ length) exhibited lower bending stiffness but higher strength in negative out-of-plane direction.

2) For in-plane bending tests, all specimens showed much lower rotational stiffness and strength than those in out-of-plane directions. Those of TB440 and HB (H-section bracket) exhibited nearly twice than those of TB300, which is caused by the effects of shear resistance of lag-screw bolts.

3) Comparing with the test results, the proposed detailed analysis methods well evaluate bending moment - rotational angle relationship, while the ultimate strengths are a little overestimated. In addition, proposed simple formulas estimate the test results in safer sides, and considered as valid for practical use.

4) TB300 has higher rotational stiffness and strength in negative out-of-plane direction than the ones in positive out-ofplane direction. However, TB440 has lower rotational stiffness and higher strength in negative out-of-plane direction than the ones in positive out-of-plane direction. As for in-plane rotational stiffness and strength, they are lower than the ones in out-ofplane direction. Therefore, the difference of rotational stiffness in out-of-plane/in-plane directions has to be considered when evaluating buckling strength of timber grid-shell structures.

(2018 年 12 月 10 日原稿受理, 2019 年 2 月 19 日採用決定) 